\title{
Elucidation of the metabolic pathway for dibenzothiophene desulphurization by Rhodococcus sp. strain IGTS8 (ATCC 53968)
}

\author{
Christopher Oldfield, ${ }^{1}+$ Olga Pogrebinsky, ${ }^{1}$ Julie Simmonds, ${ }^{1}$ \\ Edwin S. Olson ${ }^{2}$ and Charles F. Kulpa ${ }^{3}$
}

Author for correspondence: Christopher Oldfield. Tel : +44 131455 2217. Fax : +441314552291. e-mail : c.oldfield@napier.ac.uk

1 Energy Biosystems Corporation, 4200 Research Forest Drive, The Woodlands, TX 77381, USA

2 Energy and Environmental Research Center, University of North Dakota, Grand Forks, ND 58202, USA

3 Department of Biological Sciences, University of Notre Dame, Notre Dame, IN 46556-0309, USA

\begin{abstract}
Rhodococcus sp. strain IGTS8 (ATCC 53968) is able to utilize dibenzothiophene (DBT) as a sole source of sulphur. The carbon skeleton of DBT is not metabolized and is conserved as 2-hydroxybiphenyl (HBP), which accumulates in the medium. This phenotype is due to the expression of the plasmidencoded DBT-desulphurization (dsz) operon, which encodes three proteins, DszA, B and C. In this paper it is shown, using [ $\left.{ }^{35} S\right]$ DBT radiolabelling studies, that sulphur is released in the form of inorganic sulphite. The pathway of DBT desulphurization is described in detail. In summary, DszC catalyses the stepwise S-oxidation of DBT, first to dibenzothiophene 5-oxide (DBTO) and then to dibenzothiophene 5,5-dioxide $\left(\mathrm{DBTO}_{2}\right)$; DszA catalyses the conversion of $\mathrm{DBTO}_{2}$ to 2-(2'-hydroxyphenyl)benzene sulphinate (HBPSi-) and DszB catalyses the desulphination of HBPSi- to give HBP and sulphite. Studies with cell-free extracts show that DszA and DszC, but not DszB, require NADH for activity. ${ }^{18} \mathrm{O}_{2}$-labelling studies show that each incorporated oxygen atom is derived directly from molecular oxygen. These results are consistent with the role of DszC as a mono-oxygenase, of DszA as an apparently unique enzyme which catalyses the reductive hydroxylation of $\mathrm{DBTO}_{2}$ leading to cleavage of the thiophene ring, and of DszB as an aromatic sulphinic acid hydrolase.
\end{abstract}

Keywords : Rhodococcus sp. strain IGTS8, fossil fuel desulphurization, clean technologies, desulphurizing enzymes

\section{INTRODUCTION}

Crude oil and its distillates contain significant amounts of low-molecular-mass organosulphur compounds such as alkyl- and cycloalkyl thiols, alkyl- and arylthioethers and aromatic heterocycles based on thiophene. This last group includes thiophene itself, benzothiophene, dibenzothiophene, and their alkylated derivatives. Combustion of these compounds results in the release into

† Present address: Department of Biological Sciences, Napier University, Edinburgh EH10 5DT, UK.

Abbreviations: BPSi, biphenylenesultine (dibenz[c,e][1,2]oxathiin-6oxide); BPSo, biphenylenesultone (dibenz[c,e][1,2]oxathiin-6,6-dioxide); DBT, dibenzothiophene; DBTO, dibenzothiophene-5-oxide; $\mathrm{DBTO}_{2}$, dibenzothiophene 5,5-dioxide; DHBP, 2,2'-dihydroxybiphenyl; HBP, 2hydroxybiphenyl; HPBS', 2-(2'-hydroxyphenyl)benzenesulphinate; HBPSo-, 2-(2'-hydroxyphenyl)benzenesulphonate; SRM, standard Rhodococcus medium; SRMS, SRM supplemented with histidine, isoleucine, valine and biotin; TEAS, tetraethylammonium sulphonate. the atmosphere of sulphur oxyacids $\left(\mathrm{SO}_{x}\right)$ and hence to acid rain. Atmospheric $\mathrm{SO}_{x}$ is a major contributing factor to poor air-quality in the city environment and acid rain is a primary cause of global deforestation since it lowers the soil $\mathrm{pH}$ to levels intolerable for many trees and plants. As a consequence legislation has been enacted by Scandinavia, the EU, the USA and Japan which requires progressive annual reductions in the sulphur content of petrochemicals (CONCAWE, 1994).

Thus there is considerable interest in the development of petrochemical desulphurization technologies. One approach involves the application of micro-organisms selected for their ability to specifically degrade the organosulphur component. A key organism in this context is IGTS8 (ATCC 53968), provisionally identified as a strain of Rhodococcus erythropolis (M. Goodfellow, C. Oldfield, A. S. A. Teboli, M. D. Collins \& J. Chun, unpublished results) which is capable of utilizing dibenzothiophene (DBT; see Fig. 4 for structure) as sole 
source of sulphur. Previous work has shown that strain IGTS8 degrades DBT to 2-hydroxybiphenyl (HBP). HBP is not further metabolized and IGTS8 is unable to use DBT as a source of carbon (Kayser et al., 1993). A number of alkyl-substituted derivatives of DBT have also been shown to be desulphurized to the corresponding monophenol (Ohshiro et al., 1996a). This 'desulphurization' phenotype is conferred by the plasmid-located $d s z$ operon, which encodes three proteins, DszA, B and C (Denome et al., 1993, 1994). Expression of the $d s z$ operon enzymes is repressed by sulphide, sulphate, methionine and cysteine ( $\mathrm{Li}$ et al., 1996; Ohshiro et al., 1996b). GC-MS analysis of ethyl acetate extracts of strain IGTS8 culture media containing DBT as sole sulphur source revealed the presence of dibenzothiophene 5-oxide (DBTO), dibenzothiophene 5,5-dioxide $\left(\mathrm{DBTO}_{2}\right)$, biphenylene sultine (BPSi), biphenylene sultone (BPSo) and 2,2'-dihydroxybiphenyl (DHBP), in addition to HBP (Olson et al., 1993). Based on these observations, several alternative desulphurization pathways were outlined (Gallagher $e t$ al., 1993).

This paper reports a detailed characterization of the DBT-desulphurization pathway of strain IGTS8. Experiments with $\left[{ }^{35} S\right] D B T$ were carried out to identify the sulphur-containing product of the reaction. In order to identify the precise metabolic route from DBT to HBP, all of the sulphur-containing intermediates identified by Olson et al. (1993) were chemically synthesized and incubated with whole cells of strain IGTS8, with product analysis by GC-MS. The identity of the $d s z$-operon gene products responsible for each step in the pathway was deduced from experiments in which Escherichia coli subclones producing DszA, DszB or DszC were incubated with the various intermediates. Experiments with cell-free extracts of strain IGTS8 were carried out to deduce which of the $d s z$ operon enzymes required $\mathrm{NADH}$ for activity. Finally, ${ }^{18} \mathrm{O}$ labelling studies were carried out to ascertain which of the steps in the pathway require molecular oxygen.

\section{METHODS}

Materials. Suppliers were as follows: sulphite oxidase [suspension in $2 \cdot 3 \mathrm{M}\left(\mathrm{NH}_{4}\right)_{2} \mathrm{SO}_{4}$ ], bovine-heart cytochrome $c$, the buffers HEPES and HEPPS, Gibbs reagent (2,6-dichloroquinone 4-chloroimide) and ACS-grade sodium sulphite, Sigma; ACS-grade $\mathrm{H}_{2} \mathrm{O}_{2}(30 \%)$, DBT $(99+\%)$, DBTO (97\%), HBP (sold as 2-phenylphenol; $99+\%$ ) and DHBP (99\%), Aldrich; t-butyl hypochlorite, K+K Laboratories; ${ }^{18} \mathrm{O}_{2} \quad\left(96\right.$ atom \%), ICON; $\left.{ }^{35} \mathrm{~S}\right] \mathrm{DBT} \quad\left(11.3 \mathrm{Ci} \mathrm{mmol}^{-1}\right.$; $\left.418 \mathrm{GBq} \mathrm{mmol}{ }^{-1}\right), \mathrm{Na}_{2}{ }^{35} \mathrm{SO}_{3}\left(1 \cdot 3 \mathrm{Ci} \mathrm{mmol}^{-1} ; 48 \mathrm{GBq} \mathrm{mmol}^{-1}\right)$ and $\mathrm{Na}_{2}{ }^{35} \mathrm{SO}_{4}\left(78.5 \mathrm{mCi} \mathrm{mmol}^{-1} ; 2.9 \mathrm{GBq} \mathrm{mmol}^{-1}\right)$, New England Nuclear. Nanopure water from a Barnstead system was used throughout.

BPSi and BPSo were prepared according to the method of Hanson \& Kemp (1981). $\mathrm{HBPSi}^{-}$(as sodium salt) was prepared immediately prior to use by hydrolysis of BPSi with $10 \mathrm{mM}$ $\mathrm{NaOH}$, followed by titration back to neutral $\mathrm{pH}$ with $\mathrm{HCl}$.

DBTO was prepared as follows. A solution of DBT $(5 \mathrm{~g})$ in $60 \mathrm{ml}$ methanol was placed in a three-necked flask equipped with a reflux condenser, dropping funnel and nitrogen inlet and outlet tubes. The flask was maintained at a temperature of $-64^{\circ} \mathrm{C}$ in a chloroform/liquid nitrogen bath. t-Butyl hypochlorite $(3 \mathrm{~g})$ was added and the mixture stirred for $30 \mathrm{~min}$. Anhydrous sodium carbonate $(3 \mathrm{~g}$, prepared by drying at $210^{\circ} \mathrm{C}$ overnight) was then added and the mixture allowed to warm to room temperature, with stirring. The solution was filtered and the methanol removed by rotary evaporation. The white solid was recrystallized from methanol. GC-MS analysis of the product indicated DBTO at $99 \cdot 2 \%$ purity.

DBT, DBTO, $\mathrm{DBTO}_{2}$, BPSi and BPSo were stored in solid form in a desiccator at room temperature. There was no evidence of decomposition, as judged by GC-MS, over the period of this study.

Bacteria. Rhodococcus sp. strain IGTS8 (ATCC 53968) was obtained from J. Kilbane (Institute of Gas Technology, Chicago, IL, USA). Strain CPE648, generated from IGTS8 by UV mutagenesis and lacking the entire $d s z$ operon, was used as a control organism. Strain CPE648 was transformed with plasmid pENOK3 to obtain a strain expressing DszC activity only (Piddington et al., 1995). CPE648 and pENOK3 were obtained from C. Piddington (Panlabs, Inc., Bothell, WA, USA).

The recombinant $E$. coli strains used in this work have already been described (Denome et al., 1994). The host strain was $E$. coli strain MZ-1 transformed with plasmids pSAD267-1 (expressing DszA), pSAD277-7A (DszB), pSAD269-2A (DszC), or pSAD262-1 (no insert). The plasmids each carry the ampicillin-resistance marker. Expression of the recombinant genes is under the control of the bacteriophage $\lambda P_{\mathrm{L}}$ promoter and the thermolabile $\lambda c{ }^{857}$ repressor.

Culture conditions. Rhodococcus sp. strain IGTS8 was cultured in standard Rhodococcus medium (SRM), which has the following composition (per litre): $\mathrm{Na}_{2} \mathrm{HPO}_{4}, 4.33 \mathrm{~g}$; $\mathrm{KH}_{2} \mathrm{PO}_{4}, 2.65 \mathrm{~g}$; glucose, $20 \mathrm{~g} ; \mathrm{NH}_{4} \mathrm{Cl}, 2 \mathrm{~g} ; \mathrm{MgCl}_{2} .6 \mathrm{H}_{2} \mathrm{O}$, $0.64 \mathrm{~g}$; nitrilotriacetic acid, $0 \cdot 1 \mathrm{~g} ; \mathrm{CaCl}_{2} .2 \mathrm{H}_{2} \mathrm{O}, 33 \mathrm{mg} ; \mathrm{ZnCl}_{\text {, }}$, $2.6 \mathrm{mg} ; \mathrm{FeCl}_{2} .4 \mathrm{H}_{2} \mathrm{O}, 2.6 \mathrm{mg}$; EDTA, $1.25 \mathrm{mg} ; \mathrm{MnCl}_{2} .4 \mathrm{H}_{2} \mathrm{O}$, $1.0 \mathrm{mg} ; \mathrm{CuCl}_{2} .2 \mathrm{H}_{2} \mathrm{O}, 0.15 \mathrm{mg}$; $\mathrm{Co}\left(\mathrm{NO}_{3}\right)_{2} .6 \mathrm{H}_{2} \mathrm{O}, 0.125 \mathrm{mg}$; $\mathrm{Na}_{2} \mathrm{~B}_{4} \mathrm{O}_{7} .10 \mathrm{H}_{2} \mathrm{O}, 0.10 \mathrm{mg}$; $\left(\mathrm{NH}_{4}\right)_{6} \mathrm{Mo}_{7} \mathrm{O}_{24} .4 \mathrm{H}_{2} \mathrm{O}, 0.09 \mathrm{mg}$. Glucose was added as a filter-sterilized solution after autoclaving $\left(121^{\circ} \mathrm{C}, 20 \mathrm{~min}\right)$. The final $\mathrm{pH}$ was $7 \cdot 2$ without titration.

Sodium sulphate $(1.5 \mathrm{mM})$ was used as a sulphur source for cultures of IGTS8 expressing no desulphurizing activity. DMSO (1.5 mM, added after autoclaving) was substituted for sulphate to obtain IGTS8 expressing DBT-desulphurizing activity. [Note: DMSO is not a substrate for the DBTdesulphurizing enzyme system. Thus $d s z$ mutants of strain IGTS8, such as CPE648, grow equally well with DMSO. Expression of DBT-desulphurization activity in the presence of DMSO is due to the derepression of the $d s z$ operon in the absence of more readily bioavailable sulphur (sulphide, sulphate, cysteine and methionine ( $\mathrm{Li}$ et al., 1996).] Cells grown with DMSO were entirely free of DBT metabolites as judged by GC-MS. For certain experiments cells were grown with DBT or one of the putative metabolic intermediates as sole sulphur source, added following autoclaving from a stock solution $(40 \mathrm{mM}$ in acetonitrile; except $\mathrm{BPSi}, 10 \mathrm{mM}$ in ethanol), to a final concentration of $200 \mu \mathrm{M}$ (final solvent concentration $<1 \%, v / v)$. Cultures of CPE648 were grown using $1.5 \mathrm{mM}$ sulphate or $1.5 \mathrm{mM}$ DMSO as required.

Cultures were maintained on SRM agar plates (Bacto Difco agar, $20 \mathrm{~g} \mathrm{l}^{-1}$ ) containing either $200 \mu \mathrm{M} \mathrm{DBTO}_{2}$ (strain IGTS8) or $1.5 \mathrm{mM}$ sulphate (strain CPE648), subcultured every week. 
Liquid media ( $250 \mathrm{ml}$ in a 21 Erlenmeyer flask) were inoculated with a loopful of cells from the plate and incubated in an orbital shaker $\left(250\right.$ r.p.m., $\left.30^{\circ} \mathrm{C}\right)$ until the end of the exponential growth phase (approximately $80 \mathrm{~h}$ ). The specific activity for DBT-desulphurization was maximal at this point (C. Oldfield \& J. Simmonds, unpublished data). The cells were recovered by centrifugation $(15000 \mathrm{~g}$ for $15 \mathrm{~min})$, washed twice by re-suspension in 10 vols $50 \mathrm{mM}$ HEPPS buffer, $\mathrm{pH} 8.0$, and finally resuspended in the same buffer to a density of approximately $\mathrm{OD}_{600} 250$ (Beckman DU $700 \mathrm{UV}$-vis spectrophotometer, $1 \mathrm{~cm}$ path-length cell), equivalent to $88 \mathrm{~g}$ dry weight $l^{-1}$. The suspension was kept on ice and used on the day of harvesting.

Standard Gibbs assay for HBP. The stock $\mathrm{OD}_{600} 250$ cell suspension was diluted with $50 \mathrm{mM}$ HEPPS, $\mathrm{pH} 8.0$, to a nominal $\mathrm{OD}_{600}$ of $1 \cdot 0$. This was done by diluting the suspension to give a spectrophotometer reading of $\mathrm{OD}_{600}$ $0 \cdot 1-0 \cdot 2$, and calculating the dilution factor required to obtain an $\mathrm{OD}_{600}$ of 1.0 [OD $_{600} 1.0$ corresponds to a cell density of $0.35 \mathrm{~g}$ (dry wt) $\mathrm{l}^{-1}$ ]. Substrate $(25 \mu \mathrm{M}$ final concentration, introduced from a $40 \mathrm{mM}$ stock in acetone, except for BPSi, $10 \mathrm{mM}$ in ethanol) was added to $40 \mathrm{ml}$ freshly diluted $\mathrm{OD}_{600}$ 1.0 cell suspension in a $100 \mathrm{ml}$ stoppered Erlenmeyer flask and incubated in an orbital shaker $\left(240\right.$ r.p.m., $\left.30^{\circ} \mathrm{C}\right)$ for $60 \mathrm{~min}$. At 10 min intervals $1.5 \mathrm{ml}$ aliquots were removed to Eppendorf tubes and centrifuged ( 12000 r.p.m., $5 \mathrm{~min}$ ) to remove cells. A $1.0 \mathrm{ml}$ aliquot of the supernatant was transferred to a $1 \mathrm{ml}$ disposable spectrophotometer cuvette and stored at $4{ }^{\circ} \mathrm{C}$ until the end of the incubation. Gibbs reagent $(10 \mu \mathrm{l}, 10 \mathrm{mM}$ in acetone) was then added to each cuvette. A blank solution (HEPPS buffer pH 8.0 plus $10 \mu \mathrm{l}$ Gibbs reagent) was also prepared. The assays were incubated overnight at $30^{\circ} \mathrm{C}$, for full colour development, and the $A_{610}$ was measured. The $\Delta A_{610}$ was converted to HBP concentration using a standard curve prepared with authentic HBP in the range $0-30 \mu \mathrm{M}$. The linear regression slope of a plot of $\mathrm{HBP}$ concentration vs time gave the reaction rate $\left(\mu \mathrm{M} \mathrm{h}^{-1}\right)$; the specific activity $\left(\mu \mathrm{mol} \mathrm{g}^{-1} \mathrm{~h}^{-1}\right)$ was obtained by dividing the rate by the cell concentration ( $\mathrm{g}$ dry wt $\mathrm{l}^{-1}$ ). The substrate concentration used was about twice that which could be converted by an $\mathrm{OD}_{600}$ 1.0 suspension of cells in $1 \mathrm{~h}$ [specific activities were typically of the order of $25-40 \mu \mathrm{mol}(\mathrm{g} \text { dry wt})^{-1} \mathrm{~h}^{-1}$ ]. Under these conditions the plots of $\mathrm{HBP}$ concentration vs time were invariably linear (see Fig. 3).

Strain IGTS8 also converted BPSo to DHBP. This reaction was assayed using the standard Gibbs assay as described above, except that authentic DHBP was used to construct the standard curve.

Spectrophotometric assay for sulphite. Sulphite was estimated on a routine basis using a modification of the sulphite-oxidase-linked assay (oxidation of sulphite to sulphate, linked to the reduction of cytochrome $c$ ) described by Beutler (1987). The assay was carried out as described above for HBP except that at the end of the incubation cytochrome $c(20 \mu \mathrm{l}$ of a $5 \mathrm{mM}$ solution in $50 \mathrm{mM}$ HEPPS, $\mathrm{pH} 8)$ was added to each cuvette. Assays were incubated at room temperature for $5 \mathrm{~min}$ and the $A_{550}$ was read. Two microlitres of the Sigma sulphite oxidase suspension was then added to each cuvette and the set was incubated at room temperature for a further $5 \mathrm{~min}$. The $A_{550}$ was read again and the $\Delta A_{550}$ was converted to sulphite concentration using a standard curve prepared with sodium sulphite.

Reversed-phase (RP-) HPLC assay for organic metabolites. The assay was carried out as for the Gibbs HBP assay except that $0.75 \mathrm{ml}$ aliquots were removed to Eppendorf tubes at each
10 min time-point and an equal volume of acetonitrile added, with thorough mixing. The cells were removed by centrifugation (12000 r.p.m. for $5 \mathrm{~min}$ ). The supernatant was analysed using a Hewlett-Packard series 1050 liquid chromatograph equipped with a diode-array detector and fitted with a Synchropak RPC18 column $(4.6 \times 100 \mathrm{~mm})$ and a $10 \mu \mathrm{l}$ loop. The column was eluted with helium-degassed phosphate buffer $(10 \mathrm{mM}, \mathrm{pH} 6 \cdot 0) /$ acetonitrile, $(1: 1, \mathrm{v} / \mathrm{v})$ and washed with acetonitrile between runs. Approximate retention times (min) were as follows: HEPPS buffer, $0 \cdot 8$; DHBP, $1 \cdot 1$; DBTO, $1 \cdot 2$; $\mathrm{DBTO}_{2}, 1 \cdot 5$; HBP, $1 \cdot 8$; BPSi, 1.9 ; BPSo, $2 \cdot 1$; DBT, 4.6. Any ambiguities in assigning metabolite peaks were resolved by comparing the diode-array spectra with those of standards.

lon-pairing (IP-) HPLC assay for HBPSi ${ }^{-}$. IP-HPLC was carried out using the same column and flow conditions as for RPHPLC. The column was equilibrated in, and eluted with, ionpairing buffer [ $40 \mathrm{mM}$ TEAS dissolved in phosphate buffer, $(10 \mathrm{mM}, \mathrm{pH} \mathrm{6.0)} /$ acetonitrile $(90: 10, \mathrm{v} / \mathrm{v})]$. Under these conditions HPBSi eluted at $4.1 \mathrm{~min}$. Quantification of $\mathrm{HBPSi}^{-}$ at concentrations $<25 \mu \mathrm{M}$ (i.e. in the standard assay concentration range) was found to be unreliable due to the comparatively low absorption coefficient of $\mathrm{HBPSi}^{-}$in the UV-visible range. Nevertheless, the technique was useful for qualitative analysis.

[ ${ }^{35}$ S]DBT radiolabelling studies. Strain IGTS8 was grown in SRM with either DBT (unlabelled) or $\mathrm{Na}_{2} \mathrm{SO}_{4}$ as sole sulphur source. The stock $\mathrm{OD}_{600} 250$ cell preparation was diluted to $\mathrm{OD}_{600} 1 \cdot 0$ with $50 \mathrm{mM}$ HEPPS, pH 8.0. $\left[{ }^{35} \mathrm{~S}\right] \mathrm{DBT}$ (supplied as a solution in ethanol) was diluted with unlabelled DBT to give a stock solution $(25 \mathrm{mM}$ in ethanol; specific activity $43 \mathrm{mCi} \mathrm{mmol}^{-1} ; 1.59 \mathrm{GBq} \mathrm{mmol}^{-1}$ ). Sixteen microlitres was added to $40 \mathrm{ml}$ of each cell suspension (final DBT concentration, $10 \mu \mathrm{M}$ ) and incubated in an orbital shaker ( 250 r.p.m., $30^{\circ} \mathrm{C}$ ) for $10 \mathrm{~min}$. Aliquots $(1 \mathrm{ml})$ were withdrawn at 2 min intervals and the cells were removed by centrifugation. Supernatants were analysed by ion-exchange chromatography using a Dionex 2000i/SP chromatograph equipped with an anion micromembrane suppresser loaded with $12.5 \mathrm{mM} \mathrm{H}_{2} \mathrm{SO}_{4}$. Sample aliquots $(50 \mu \mathrm{l})$ were eluted from an Ion-Pac AG9-SC analytical column using a mobile phase of $1.8 \mathrm{mM} \mathrm{Na}_{2} \mathrm{CO}_{3}$ and $1.7 \mathrm{mM} \mathrm{NaHCO}_{3}$ at a flow-rate of $2.0 \mathrm{ml} \mathrm{min}-1$. Fractions of $500 \mu \mathrm{l}$ were collected and diluted into $10 \mathrm{ml}$ scintillation fluid. Radioactivity in each vial was measured by counting for $10 \mathrm{~min}$ in a Beckman LS 5000 scintillation counter, with c.p.m./d.p.m. conversion based on $85 \%$ counting efficiency for ${ }^{35} \mathrm{~S}$ measured using authenticated standards. Quenching was negligible at the count rates obtained in these experiments. Authentic ${ }^{35} \mathrm{SO}_{3}^{2-}$ and ${ }^{35} \mathrm{SO}_{4}^{2-}$ eluted at approximately $7 \cdot 1$ and $9.1 \mathrm{~min}$, respectively. Counts were recovered with $>95 \%$ efficiency.

Isolation of organic metabolites and GC-MS analysis. Strain IGTS8 was grown in SRM with DMSO as sole sulphur source. A $100 \mathrm{ml}$ volume of the $\mathrm{OD}_{600} 250$ cell suspension (approximately $9 \mathrm{~g}$ dry wt of cells) was diluted to $400 \mathrm{ml}$ with $50 \mathrm{mM}$ HEPPS buffer, $\mathrm{pH} 8 \cdot 0$. The required substrate was added to final concentration of $200 \mu \mathrm{M}$ and the suspension was incubated overnight in an orbital shaker $\left(250\right.$ r.p.m., $\left.30^{\circ} \mathrm{C}\right)$. The cells were then removed by centrifugation and the supernatant was titrated to $\mathrm{pH} 1$ with $\mathrm{HCl}$. An equal volume of ethyl acetate was added and the mixture stirred for $4 \mathrm{~h}$. The ethyl acetate phase was recovered and dried by stirring for $1 \mathrm{~h}$ with anhydrous $\mathrm{MgSO}_{4}$. The ethyl acetate was removed by rotary evaporation and the solids were redissolved in $3 \mathrm{ml}$ ethyl acetate. Uncharged compounds such as DBT, DBTO, $\mathrm{DBTO}_{2}$ and BPSo partitioned readily into the organic phase and $\mathrm{HBPSi}^{-}$transferred after first condensing to $\mathrm{BPSi}$, a 


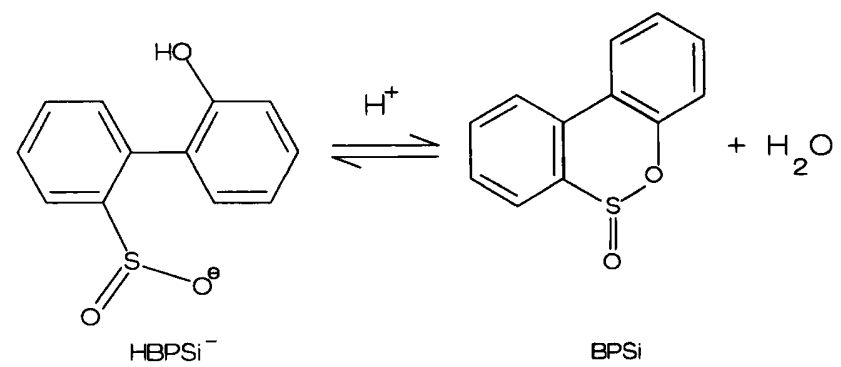

Fig. 1. The $\mathrm{pH}$-dependent interconversion between $\mathrm{HBPSi}^{-}$and BPSi. The $\mathrm{HBPSi}^{-} \leftrightarrow \mathrm{BPSi}$ equilibrium is shifted right on decreasing the $\mathrm{pH}$. At $\mathrm{pH} 1, \mathrm{BPSi}$ is the sole species. The interconversion was followed by UV spectrophotometry (Hanson \& Kemp, 1981).

reaction favoured by low $\mathrm{pH}$ (Fig. 1). GC-MS analysis was carried out as described previously (Olson et al., 1993).

${ }^{18} \mathrm{O}_{2}$-labelling studies. Strain IGTS8 was grown with DMSO as sole sulphur source. A $25 \mathrm{ml}$ aliquot of the $\mathrm{OD}_{600} 250$ cell suspension was placed in a $50 \mathrm{ml}$ polypropylene centrifuge tube and capped with a rubber septum carrying a syringe needle. The tube was alternately degassed by vacuum and flushed with helium $(3 \times 10 \mathrm{~min}$ cycles $)$. After the final evacuation the syringe needle was removed. Substrate was added to a final concentration of $200 \mu \mathrm{M}$, and ${ }^{18} \mathrm{O}_{2}(96$ atom $\%$ ) was introduced to a pressure slightly above $1 \mathrm{~atm}$, using gas-tight microsyringes. The tube was incubated overnight $\left(30^{\circ} \mathrm{C}\right.$ with shaking) and the reaction products were extracted and analysed by GC-MS as described above.

Preparation and assay of cell-free extracts. Strain IGTS8 was grown in SRM with DMSO as sole sulphur source. The cells were washed twice with 10 vols $50 \mathrm{mM}$ HEPES, $\mathrm{pH} 7 \cdot 5$, and resuspended in the same buffer, containing DTT $(1 \mathrm{mM})$ and PMSF $\left(30 \mu \mathrm{g} \mathrm{ml}^{-1}\right)$, to $\mathrm{OD}_{600} 250$. The cells were broken by a single pass through a French pressure cell at an operating pressure of 2200 p.s.i. (15.2 MPa). $\mathrm{MgCl}_{2}$ (10 mM), DNase $\left(0.1 \mathrm{mg} \mathrm{ml}^{-1}\right)$ and RNase $\left(0.1 \mathrm{mg} \mathrm{m}^{-1}\right)$ were added and the mixture was stirred at $4{ }^{\circ} \mathrm{C}$ for $30 \mathrm{~min}$. Cell debris was removed by centrifugation at $39800 \mathrm{~g}$ for $60 \mathrm{~min}$. The supernatant was diluted to $10 \mathrm{mg}$ protein $\mathrm{ml}^{-1}$ with $50 \mathrm{mM}$ HEPES, pH 7·5. Protein concentrations were estimated using the Bio-Rad protein assay kit. The extract was divided into portions and the required substrate was added to $100 \mu \mathrm{M}$. $\mathrm{NADH}$, if required, was added to $4 \mathrm{mM}$. The preparations were incubated at $30^{\circ} \mathrm{C}$ for $60 \mathrm{~min}$. At $10 \mathrm{~min}$ intervals $0.75 \mathrm{ml}$ aliquots were removed, diluted with an equal volume of acetonitrile and centrifuged at 12000 r.p.m. for $10 \mathrm{~min}$ to remove precipitated protein. Supernatants were analysed by RP-HPLC as described above. Specific activities were calculated by dividing the slope of the product concentration (corrected for acetonitrile dilution) vs time plots by the protein concentration.

Growth and assay of $E$. coli recombinants expressing Dsz proteins. E. coli strain MZ-1 was grown in SRMS, i.e. SRM supplemented with histidine, isoleucine and valine (each $\left.50 \mathrm{mg} \mathrm{ml}^{-1}\right)$, biotin $\left(0.4 \mathrm{mg} \mathrm{l}^{-1}\right)$, ampicillin $\left(100 \mu \mathrm{g} \mathrm{m}^{-1}\right)$ and $\mathrm{Na}_{2} \mathrm{SO}_{4}(1.5 \mathrm{mM})$. The cells were maintained on SRMS agar plates (Bacto Difco agar, $20 \mathrm{~g} \mathrm{l}^{-1}$ ).

Starter cultures were prepared by inoculating $50 \mathrm{ml}$ sterile SRMS in a $250 \mathrm{ml}$ Erlenmeyer flask with cells from a single colony and incubating overnight in an orbital shaker ( 250 r.p.m., $30^{\circ} \mathrm{C}$ ). Then $500 \mathrm{ml}$ of SRMS in a 21 Erlenmeyer flask was inoculated with $10 \mathrm{ml}$ starter culture and incubated under the same conditions to $\mathrm{OD}_{600} 0.4$ (about $4.5 \mathrm{~h}$ ). The temperature was then raised to $39^{\circ} \mathrm{C}$ for $2 \mathrm{~h}$ to derepress the Dsz proteins. The cells were recovered by centrifugation (15000 $\mathrm{g}$ for $15 \mathrm{~min}$ ), washed twice with 10 vols SRMS and finally resuspended in SRMS to a nominal $\mathrm{OD}_{600}$ of 10 . The required substrate was added to a final concentration of $100 \mu \mathrm{M}$. After overnight incubation in an orbital shaker (250 r.p.m.; $30^{\circ} \mathrm{C}$ ), $0.75 \mathrm{ml}$ aliquots were transferred to Eppendorf tubes and the cells removed by centrifugation (12000 r.p.m., $10 \mathrm{~min}$ ). The supernatant was diluted with an equal volume of acetonitrile, vortexed thoroughly and analysed by RP-HPLC and IP-HPLC, as described above.

\section{RESULTS}

\section{Sulphite is the sulphur-containing product of the desulphurization reaction}

To identify the sulphur-containing product of the desulphurization reaction, a batch of cells with a specific DBT-desulphurizing activity of $12 \mu \mathrm{mol} \mathrm{g}^{-1} \mathrm{~h}^{-1}$, measured using the standard Gibbs assay, was incubated with $\left[{ }^{35} \mathrm{~S}\right] \mathrm{DBT}$, as described in Methods. Ion-exchange chromatography of the recovered incubation medium revealed the presence of water-soluble radiolabelled material which eluted as a single peak with a retention time of $7 \cdot 1 \mathrm{~min}$, the same as that of ${ }^{35} \mathrm{SO}_{3}^{2-}$ (Fig. 2a). It

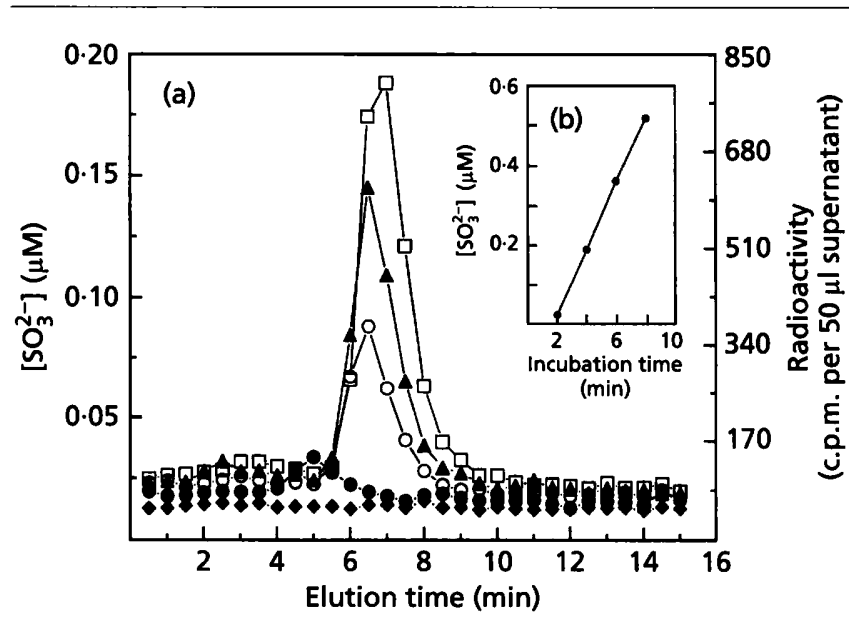

Fig. 2. Sulphite production from $\left[{ }^{35} \mathrm{~S}\right] \mathrm{DBT}$ by Rhodococcus sp. strain IGTS8. (a) Strain IGTS8 was grown in SRM with unlabelled DBT as sole sulphur source. Cells were washed twice in 10 vols

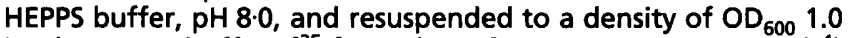
in the same buffer. [ ${ }^{35}$ S]DBT (specific activity $43 \mathrm{mCi} \mathrm{mmol}^{-1}$ ) was added to a final concentration of $10 \mu \mathrm{M}$ and the preparation was incubated in an orbital shaker ( 250 r.p.m., $30^{\circ} \mathrm{C}$ ) for $10 \mathrm{~min}$. Aliquots $(1 \mathrm{ml})$ were removed at $2 \mathrm{~min}$ intervals and the cells removed by centrifugation. The supernatants were analysed by ion-exchange chromatography as described in Methods. The peak at $7.1 \mathrm{~min}$ corresponds to $\mathrm{SO}_{3}^{2-}$ (calibration using $\mathrm{Na}_{2}{ }^{35} \mathrm{SO}_{3}$ ). Times of incubation of strain IGTS8 with [ ${ }^{35}$ ] ]DBT: $\diamond, 0 \mathrm{~min} ; 0,2 \mathrm{~min} ; 0,4 \mathrm{~min} ; \Delta, 6 \mathrm{~min}$; $\square, 8 \mathrm{~min}$. (b) Plot of medium ${ }^{35} \mathrm{SO}_{3}^{2-}$ concentration vs incubation time. The slope corresponds to a specific activity of $14 \mu \mathrm{mol}(\mathrm{g} \text { dry } \mathrm{wt})^{-1} \mathrm{~h}^{-1}$. 


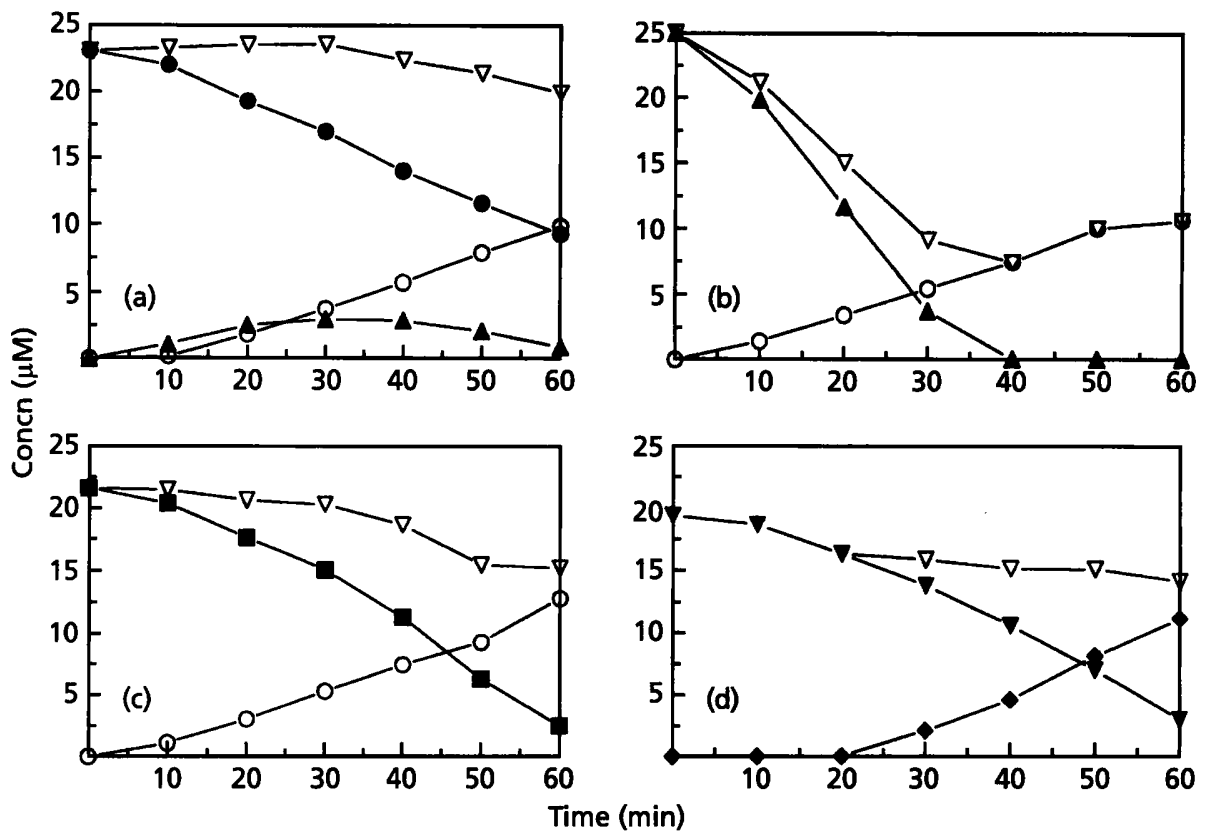

Fig. 3. Time-course of the conversion of (a) DBT, (b) DBTO and (c) DBTO ${ }_{2}$ to HBP, and of (d) BPSo to DHBP, by whole cells of Rhodococcus sp. strain IGTS8. Cells were grown to the end of the exponential phase in SRM with DBTO, as sole sulphur source, washed twice with 10 vols $50 \mathrm{mM}$ HEPPS buffer, pH 8.0, and finally resuspended in the same buffer. The suspension was portioned into $40 \mathrm{ml}$ aliquots and the required substrate was added to a final concentration of $25 \mu \mathrm{M}$. At each time-point, aliquots were withdrawn for analysis by RP-HPLC, Gibbs assay and sulphite oxidase assay, as described in Methods. DBT; $\triangle$, DBTO; $\square$, DBTO $_{2} ; O$, HBP; $\nabla$, BPSO; $\diamond$, DHBP. $\nabla$, Molar mass-balance, calculated by summing the molar substrate and product(s) concentrations at each time point. In these experiments only substrate and desulphurized product (HBP or DHBP) could be detected, except in the incubation with DBT, where DBTO was also observed. The lower limit for detection was approximately $0.5 \mu \mathrm{M}$.

was therefore concluded that sulphur was released from DBT as sulphite.

The plot of sulphite produced vs time was linear (Fig. 2b) with a slope of $5 \mu \mathrm{M} \mathrm{h}^{-1}$, corresponding to a specific desulphurization activity of $14 \mu \mathrm{mol}(\mathrm{g} \text { dry wt })^{-1} \mathrm{~h}^{-1}$. This compared well with the specific activity calculated from the assay of HBP production.

No radiolabelled sulphite was produced in incubations of sulphate-grown IGTS8 with $\left[{ }^{35} \mathrm{~S}\right] \mathrm{DBT}$ under otherwise identical conditions, and these cells likewise produced no detectable HBP.

\section{Whole cells of Rhodococcus sp. strain IGTS8 desulphurize DBT, DBTO and DBTO $_{2}$ to HBP and sulphite with equal efficiency}

Strain IGTS8, but not the $d s z$ mutant CPE648, grew in SRM containing DBT, DBTO or $\mathrm{DBTO}_{2}(200 \mu \mathrm{M})$ as the sole source of sulphur. HBP accumulated in the medium during growth, reaching a final concentration of $200 \mu \mathrm{M}$, as determined by RP-HPLC, by the end of the exponential growth phase (C. Oldfield \& J. Simmonds, unpublished data).

The kinetics of DBT, DBTO and $\mathrm{DBTO}_{2}$ desulphurization by strain IGTS8 was determined (Fig. 3, Table 1). Each of these compounds was desulphurized to HBP and sulphite with approximately the same specific activity as measured in terms of HBP or sulphite accumulation in the medium (Table 1). With DBT, reproducible transient accumulation of DBTO was observed (Fig. 3a). With DBTO and $\mathrm{DBTO}_{2}$, no peak other than HBP was apparent in any of the HPLC traces. The desulphurization of DBTO by strain IGTS8 in these experiments contradicts an earlier report (Denome et al., 1994), but was reproducible in this study.

The rate of disappearance of substrate from the medium was faster than the rate of HBP accumulation (Table 1). However after overnight incubation the HBP concentration reached the maximum value $(25 \mu \mathrm{M})$ expected assuming a 1:1 substrate:HBP reaction stoichiometry (data not shown). This phenomenon was also observed in growing cultures, where the substrate was entirely consumed in the early stages of growth but the HBP concentration did not reach the theoretical maximum until the end of the exponential growth phase (C. Oldfield \& J. Simmonds, unpublished data). It was therefore concluded that the substrate became transiently adsorbed to the cell envelope prior to conversion to HBP.

\section{DszC oxidizes DBT to $\mathrm{DBTO}_{2}$}

When E. coli strain MZ-1(pSAD269-2A), expressing $d s z C$, was incubated overnight in SRMS with DBT or DBTO $(100 \mu \mathrm{M})$, the substrate concentration was 
Table 1. Specific desulphurization activity of DBT and its metabolites by whole cells of Rhodococcus sp. strain IGTS8

The assay methods are indicated in parentheses. See legend to Fig. 3 for details of incubations. Specific activities were calculated as described in Methods, using the slopes of the plots shown in Fig. 3. Specific activities calculated in terms of product formation (HBP or DHBP and sulphite) for different batches of cells grown under the same conditions were reproducible to $\pm 5 \%$. Specific activities estimated on the basis of substrate disappearance were always fractionally larger than those estimated by product formation, but the variance was higher; this was attributed to a variable degree of binding of the substrate to the bacterial cell wall (see text).

\begin{tabular}{|lcccc|}
\hline Substrate & \multicolumn{4}{c|}{ Specific activity $\left[\mu \mathrm{mol}\left(\mathrm{g} \mathrm{dry} \mathbf{w t}^{-1} \mathbf{h}^{-1}\right]\right.$} \\
\cline { 2 - 5 } & $\begin{array}{c}\text { Substrate } \\
\text { consumption } \\
\text { (HPLC) }\end{array}$ & $\begin{array}{c}\text { HBP production } \\
\text { (HPLC) }\end{array}$ & $\begin{array}{c}\text { HBP production } \\
\text { (Gibbs) }\end{array}$ & $\begin{array}{c}\text { Sulphite } \\
\text { production } \\
\text { (sulphite } \\
\text { oxidase) }\end{array}$ \\
\hline DBT & 57 & & & 44 \\
DBTO $_{\text {DBTO }}$ & 219 & 35 & 42 & 43 \\
BPSo $^{*}$ & 54 & 38 & 40 & 49 \\
\hline
\end{tabular}

* The products of BPSo desulphurization are DHBP and sulphite.

Table 2. Metabolism of DBT desulphurization pathway intermediates by whole cells of recombinant $E$. coli strain MZ-1 expressing proteins of the dsz operon of Rhodococcus sp. strain IGTS8

Recombinant strains of $E$. coli strain MZ-1, expressing individual proteins of the $d s z$ operon of Rbodococcus sp. strain IGTS8, were grown and assayed as described in Methods. Figures in parentheses are micromolar concentrations estimated using RP-HPLC, except for $\mathrm{HBPSi}^{-}[(+)$, present, $(-)$, absent, as determined by IP-HPLC]. Products are shown in bold type. It was concluded that the concentration values for each strain/substrate combination did not sum to $100 \mu \mathrm{M}$ due to binding of substrates and/or products to the cells (see text). ND, Not determined.

\begin{tabular}{|c|c|c|c|c|c|}
\hline \multirow[t]{2}{*}{ E. coli strain } & \multicolumn{5}{|c|}{ Metabolites accumulated with substrate $(100 \mu M)$ shown: } \\
\hline & DBT & DBTO & $\mathrm{DBTO}_{2}$ & HPBSi & BPSo \\
\hline MZ-1(pSAD267-1) (DszA) & $\begin{array}{l}\operatorname{DBT}(65) \\
\operatorname{DBTO}_{(0)} \\
\text { DBTO }_{2}(0) \\
\text { HBPSi }^{-}(-) \\
\operatorname{HBP}(0)\end{array}$ & $\begin{array}{l}\text { DBT }(0) \\
\text { DBTO }(78) \\
\text { DBTO }_{2}(0) \\
\text { HBPSi }^{-}(-) \\
\text {HBP }(0)\end{array}$ & $\begin{array}{l}\text { DBT }(0) \\
\text { DBTO }^{(0)} \\
\text { DBTO }_{2}(0) \\
\text { HBPSi }^{-}(+) \\
\operatorname{HBP}(0)\end{array}$ & $\begin{array}{l}\operatorname{DBT}(0) \\
\operatorname{DBTO}_{(0)} \\
\text { DBTO }_{2}(0) \\
\text { HBPSi }^{-}(+) \\
\operatorname{HBP}(0)\end{array}$ & $\begin{array}{l}\text { BPSo (0) } \\
\text { DHBP (31) }\end{array}$ \\
\hline MZ-1(pSAD277-7A) (DszB) & $\begin{array}{l}\text { DBT }(46) \\
\text { DBTO }(0)_{\text {DBTO }_{2}(0)} \\
\text { HBPSi }^{-}(-) \\
\text {HBP }(0)\end{array}$ & $\begin{array}{l}\text { DBTO }(0) \\
\text { DBTO }_{(83)} \\
\text { DBTO }_{2}(0) \\
\text { HBPSi }^{-}(-) \\
\operatorname{HBP}(0)\end{array}$ & $\begin{array}{l}\text { DBTO }(0) \\
\text { DBTO }(0) \\
\text { DBTO }_{2}(50) \\
\mathrm{HBPSi}^{-}(-) \\
\operatorname{HBP}(0)\end{array}$ & $\begin{array}{l}\operatorname{DBT}(0) \\
\operatorname{DBTO}_{(0)} \\
\operatorname{DBTO}_{2}(0) \\
\text { HBPSi }^{-}(-) \\
\operatorname{HBP}(\mathbf{5 5})\end{array}$ & $\begin{array}{l}\text { BPSo }(68) \\
\operatorname{DHBP}(0)\end{array}$ \\
\hline MZ-1(pSAD269-2A) (DszC) & $\begin{array}{l}\text { DBT (15) } \\
\text { DBTO (5) }_{\text {DBTO }_{2}(40)} \\
\text { HBPSi }^{-}(-) \\
\text {HBP }(0)\end{array}$ & $\begin{array}{l}\text { DBT }(0) \\
\text { DBTO }^{(0)} \\
\text { DBTO }_{2}(52) \\
\text { HBPSi }^{-}(-) \\
\operatorname{HBP}(0)\end{array}$ & $\begin{array}{l}\text { DBT }(0) \\
\text { DBTO }^{(0)} \\
\text { DBTO }_{2}(74) \\
\text { HBPSi }^{-}(-) \\
\text {HBP }(0)\end{array}$ & $\begin{array}{l}\operatorname{DBT}(0) \\
\operatorname{DBTO}_{(0)} \\
\operatorname{DBTO}_{2}(0) \\
\operatorname{HBPSi}^{-}(+) \\
\operatorname{HBP}(0)\end{array}$ & $\begin{array}{l}\text { BPSo (52) } \\
\text { DHBP (0) }\end{array}$ \\
\hline $\begin{array}{l}\mathrm{MZ}-1(\mathrm{pSAD} 267-1) \\
\quad+\mathrm{MZ}-1(\mathrm{pSAD} 277-7 \mathrm{~A})(\mathrm{DszA}+\mathrm{DszB})^{*}\end{array}$ & ND & ND & $\begin{array}{l}\operatorname{DBT}(0) \\
\operatorname{DBTO}_{(0)} \\
\operatorname{DBTO}_{2}(25) \\
\mathrm{HBPSi}^{-}(-) \\
\operatorname{HBP}(23)\end{array}$ & $\begin{array}{l}\operatorname{DBT}(0) \\
\operatorname{DBTO}_{(0)} \\
\operatorname{DBTO}_{2}(0) \\
\operatorname{HBPSi}^{-}(-) \\
\operatorname{HBP}(60)\end{array}$ & ND \\
\hline
\end{tabular}

"In this experiment E. coli strain MZ-1(pSAD267-1), expressing $d s z A$, and strain MZ-1(pSAD277-7A), expressing $d s z B$, were grown and derepressed separately. Equal volumes of the washed suspensions were then mixed for the incubation. 
greatly reduced and $\mathrm{DBTO}_{2}$ was detectable in the supernatants (Table 2). In incubations with DBT, a small amount of DBTO was also detected. No other compounds were detected by RP- or IP-HPLC. No $\mathrm{DBTO}_{2}$ was detected if $d s z C$ was not first de-repressed by incubation at $39^{\circ} \mathrm{C}$ (data not shown).

When strain MZ-1(pSAD267-1), expressing $d s z A$, or strain MZ-1(pSAD277-7a), expressing $d s z B$, was incubated overnight in SRMS with DBT or DBTO, some disappearance of substrate was noted (Table 2), but no products were detected. Disappearance of substrate was once again attributed to binding of the substrate to the cell and for this reason assignments of enzymes on the reaction pathway were made exclusively on the appearance of product.

Based on these data, it was concluded that expression of the $d s z C$ gene-product alone was sufficient to confer on E. coli the ability to oxidize DBT or DBTO to $\mathrm{DBTO}_{2}$. Since DBTO, as well as DBT, is a substrate for this enzyme, and given that DBTO accumulates transiently in incubations of both strain MZ-1, expressing $d s z C$, and strain IGTS8, with DBT (Fig. 3a), it was concluded that DszC catalyses the sequential oxidation DBT $\rightarrow$ DBTO $\rightarrow$ DBTO$_{2}$. The results of the ${ }^{18} \mathrm{O}_{2}$ labelling studies, described below, were consistent with this interpretation.

\section{DszA converts $\mathrm{DBTO}_{2}$ to $\mathrm{HBPSi}^{-}$and DszB converts $\mathrm{HBPSi}^{-}$to HBP}

GC-MS analysis of ethyl acetate extracts of supernatants from incubations of strain IGTS8 (whole cells) with DBT, DBTO and $\mathrm{DBTO}_{2}$ revealed the presence of BPSi at concentrations well below the HPLC detection limit (approx. $1 \mu \mathrm{M}$ ), confirming the results of the earlier study (Olson et al., 1993).

BPSi is unstable in aqueous media at neutral $\mathrm{pH}$, and would be present solely as its hydrolysed form, $\mathrm{HBPSi}^{-}$ (Fig. 1). It was reasonable to conclude that $\mathrm{HBPSi}^{-}$is the penultimate intermediate in the desulphurization pathway since $\mathrm{HBPSi}^{-} \rightarrow \mathrm{HBP}$ would only require the cleavage of a single $\mathrm{C}-\mathrm{S}$ bond.

When E. coli strain MZ-1 (pSAD267-1), expressing $d s z A$, was incubated overnight in SRMS with $\mathrm{DBTO}_{2}, \mathrm{DBTO}_{2}$ disappeared completely from the medium, as judged by RP-HPLC of the supernatant, and $\mathrm{HBPSi}^{-}$was detected using IP-HPLC (Table 2). The presence of BPSi in ethyl acetate extracts of the acidified supernatant, as revealed by GC-MS, was consistent with the presence of HBPSi $^{-}$ in the untreated supernatant (data not shown).

When $\mathrm{DBTO}_{2}$ was incubated with cell suspensions of strain MZ-1 expressing $d s z B$ or $d s z C$, there was some disappearance of $\mathrm{DBTO}_{2}$, once again attributed to binding of the substrate to the cells (Table 2), but HBPSi $^{-}$was never detected in the supernatant and BPSi was never detected in ethyl acetate extracts. It was therefore concluded that expression of $d s z A$ was necessary and sufficient to confer on strain MZ-1 the ability to convert $\mathrm{DBTO}_{2}$ to $\mathrm{HBPSi}^{-}$.
No HBP was detectable in the $\mathrm{HBPSi}^{-}$-containing supernatant from the incubation of $\mathrm{DBTO}_{2}$ with strain MZ-1(pSAD267-1) expressing $d s z A$. However, when the supernatant was incubated overnight at $30^{\circ} \mathrm{C}$ with strain $\mathrm{MZ}-1$ (pSAD277-7A), expressing $d s z B, H B P$ was produced. This result was only obtained if the cells had first been incubated at $39^{\circ} \mathrm{C}$ to derepress $d s z B$ (data not shown). Similarly, incubation of $\mathrm{DBTO}_{2}$ with a mixture of strain MZ-1 (pSAD267-1), expressing $d s z A$, and strain MZ-1(pSAD277-7A), expressing $d s z B$, grown and derepressed separately, resulted in considerable HBP production (Table 2).

To confirm that HBPSi $^{-}$was an intermediate in the pathway, the ability of Rbodococcus sp. strain IGTS8 to use this compound as a sulphur source was investigated. Strain IGTS8 grew in SRM with HBPSi ${ }^{-}$as sole sulphur source. At the end of the exponential growth phase, HBP was the sole detectable product in the medium, as determined by RP-HPLC, and no HBPSi ${ }^{-}$was detectable by IP-HPLC (data not shown).

Strain IGTS8 grown in SRM with DMSO as sole sulphur source was unable to convert $\mathrm{HBPSi}^{-}$(Table 3). However, considerable $\mathrm{HBPSi}^{-}$-desulphurizing activity was observed in cell-free extracts (Table 3). It was therefore concluded that DszB is an intracellular enzyme, and that $\mathrm{HBPSi}^{-}$was not converted under standard assay conditions because the cell envelope is relatively impermeable to the charged HBPSi ${ }^{-}$molecule. Strain IGTS8 grew in SRM with $\mathrm{HBPSi}^{-}$as sole sulphur source and it was concluded that passage of $\mathrm{HBPSi}^{-}$across the cell envelope was not rate-limiting for growth.

It was concluded that $\mathrm{DBTO}_{2}$ was desulphurized in two steps, $\mathrm{DBTO}_{2} \rightarrow \mathrm{HBPSi}^{-} \rightarrow \mathrm{HBP}$, catalysed by DszA and Dsz $B$, respectively, and that the complete pathway is $\mathrm{DBT} \rightarrow \mathrm{DBTO} \rightarrow \mathrm{DBTO}_{2} \rightarrow \mathrm{HBPSi}^{-} \rightarrow \mathrm{HBP}+$ sulphite (Fig. 4).

\section{DszA also catalyses the conversion of BPSo to DHBP + sulphite}

BPSo was implicated as an intermediate in DBT metabolism following its recovery in very small amounts from culture media of strain IGTS8 grown on DBT (Olson et al., 1993). When whole cells of strain IGTS8 grown on DBT, DBTO, $\mathrm{DBTO}_{2}$ or DMSO were incubated under standard assay conditions with authentic BPSo, DHBP was the sole product detectable in the supernatant as determined by RP-HPLC (Fig. 3d). The identity of the $1.1 \mathrm{~min}$ RP-HPLC peak as DHBP was confirmed by GCMS (data not shown). The specific BPSo-desulphurizing activity of whole cells of strain IGTS8, measured in terms of DHBP production, was similar to that for HBP production from DBT, DBTO and $\mathrm{DBTO}_{2}$ (Table 1). The sulphur-containing product of BPSo desulphurization was sulphite, as determined by sulphite oxidase assay, and the specific activity measured in terms of sulphite production was similar to that measured for DHBP production (Table 1).

Studies with recombinant E. coli showed that BPSo desulphurization was catalysed exclusively by DszA. 
Table 3. Activity of DBT-desulphurization pathway enzymes in whole cells and cell-free extracts of Rhodococcus sp. strain IGTS8

Cells were grown to the end of the exponential phase in SRM with DMSO as sulphur source. For

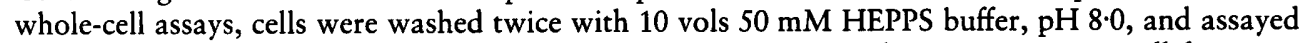
under standard assay conditions, with HBP (or DHBP) estimation by RP-HPLC. For cell-free assays cells were washed twice with 10 vols $50 \mathrm{mM}$ HEPES buffer, $\mathrm{pH} 7 \cdot 5$, and resuspended in the same buffer to $\mathrm{OD}_{600} 250$. The cell extract $\left(10 \mathrm{mg}\right.$ protein $\mathrm{ml}^{-1}$ in $50 \mathrm{mM}$ HEPES, $\left.\mathrm{pH} \mathrm{7.5}\right)$ was prepared and assayed as described in Methods, with product analysis by RP-HPLC. ND, Not determined.

\begin{tabular}{|c|c|c|c|c|}
\hline \multirow{3}{*}{$\begin{array}{l}\text { Reaction } \\
\text { catalysed }\end{array}$} & \multirow{3}{*}{$\begin{array}{c}d s z \text { operon } \\
\text { proteins } \\
\text { involved }\end{array}$} & \multicolumn{3}{|c|}{ Specific activity } \\
\hline & & \multirow{2}{*}{$\begin{array}{l}\text { Whole cells } \\
{[\mu \mathrm{mol}(\mathrm{g} \text { dry }} \\
\left.\mathrm{wt})^{-1} \mathrm{~h}^{-1}\right]\end{array}$} & \multicolumn{2}{|c|}{$\begin{array}{l}\text { Cell-free extract [ } \mu \mathrm{mol} \\
\left.\quad(\mathrm{g} \text { protein })^{-1} \mathrm{~h}^{-1}\right]\end{array}$} \\
\hline & & & $\begin{array}{l}\text { Minus } \\
\text { NADH }\end{array}$ & $\begin{array}{l}\text { Plus NADH } \\
\qquad(4 \mathrm{mM})\end{array}$ \\
\hline $\mathrm{DBT} \rightarrow \mathrm{HBP}$ & DszA, B and C & $19 \cdot 8$ & 0 & $16 \cdot 9$ \\
\hline $\mathrm{DBTO} \rightarrow \mathrm{HBP}$ & DszA, B and C & $23 \cdot 0$ & 0 & $16 \cdot 6$ \\
\hline $\mathrm{DBTO}_{2} \rightarrow \mathrm{HBP}$ & DszA and $B$ & $24 \cdot 5$ & 0 & $18 \cdot 4$ \\
\hline BPSo $\rightarrow$ DHBP & DszA only & $31 \cdot 0$ & 0 & $19 \cdot 0$ \\
\hline $\mathrm{HBPSi}^{-} \rightarrow \mathrm{HBP}$ & DszB only & $0^{*}$ & $18 \cdot 8$ & $19 \cdot 0$ \\
\hline $\mathrm{DBT} \rightarrow \mathrm{DBTO}_{2}$ & DszC onlyt & ND & 0 & $10 \cdot 0$ \\
\hline
\end{tabular}

"The inability of whole cells to metabolize $\mathrm{HBPSi}^{-}$was taken to indicate that the cell envelope of strain IGTS8 was relatively impermeable to this substrate (see text).

† Recombinant Rhodococcus sp. strain CPE648 (dsz) transformed with plasmid pENOK3, expressing $d s z C$ only, was used for this experiment.

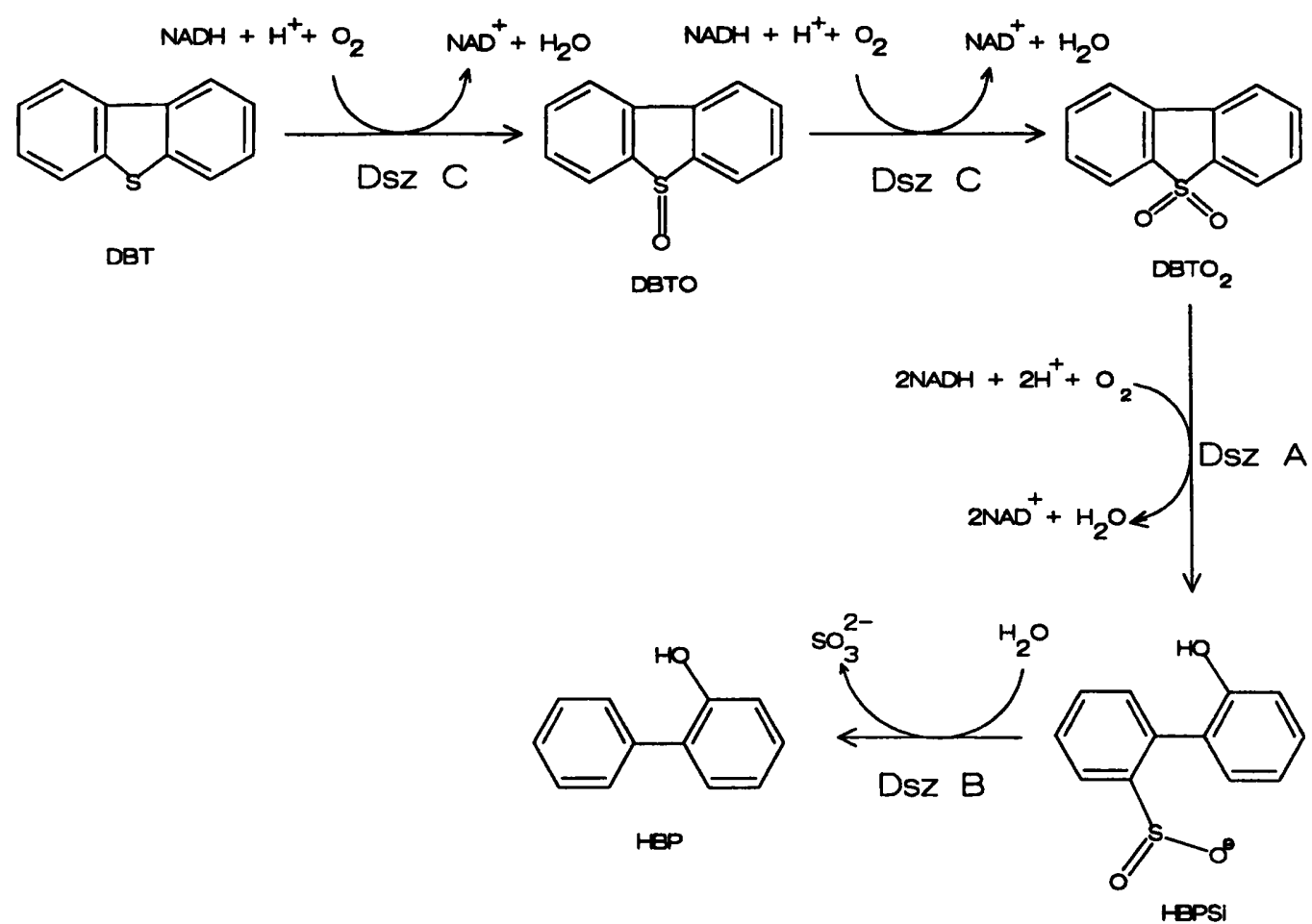

Fig. 4. Metabolic pathway for the desulphurization of DBT to HBP and sulphite by Rhodococcus sp. strain IGTS8. Actual reaction stoichiometries with respect to oxygen and NADH consumption were not measured and values given are those required for a balanced equation (see Discussion). 


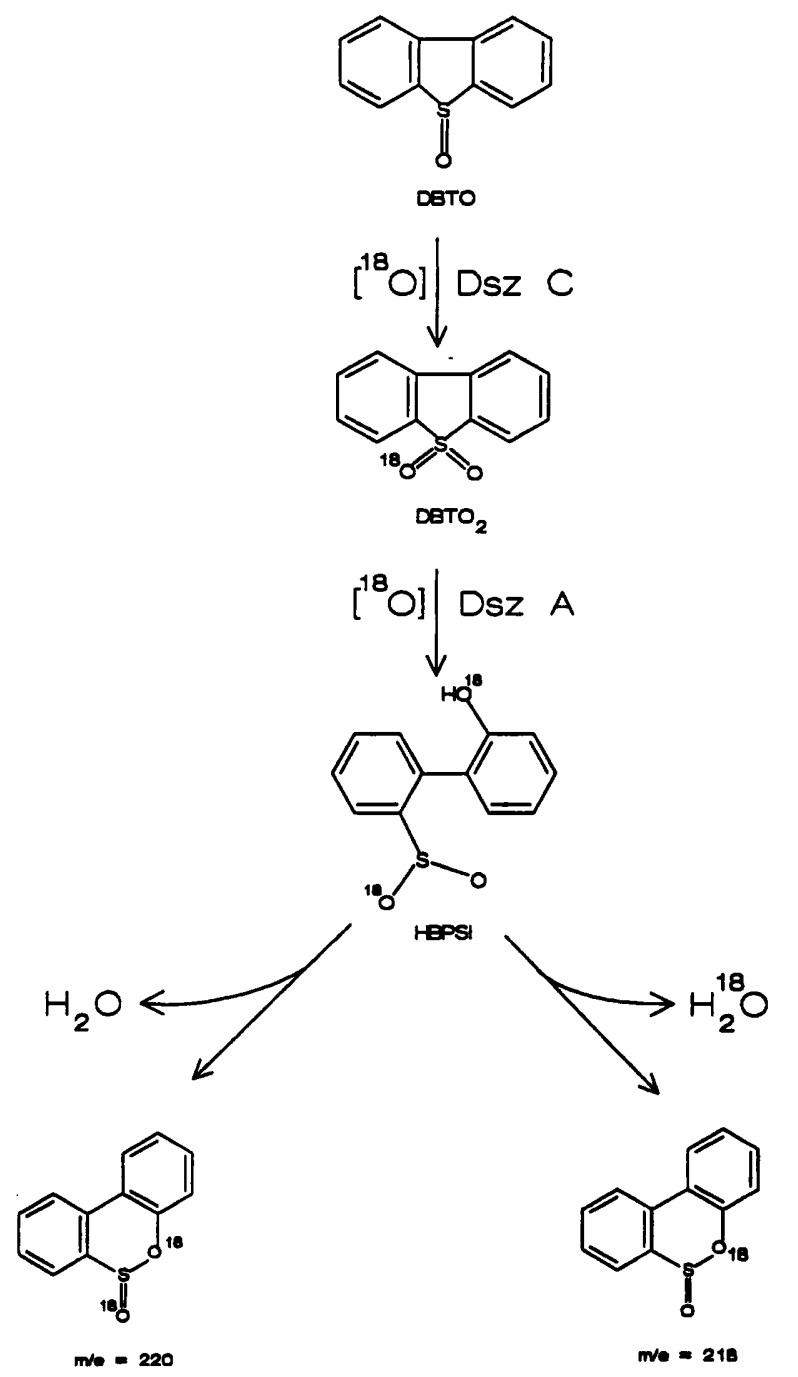

Fig. 5. ${ }^{18} \mathrm{O}$ labelling of BPSi recovered from the incubation of DBTO with whole cells of Rhodococcus sp. strain IGTS8 in the presence of ${ }^{18} \mathrm{O}_{2}$. Strain IGTS8 was grown to the end of the exponential growth phase in SRM with DMSO as a sulphur source. Cells were washed and resuspended in $50 \mathrm{mM}$ HEPPS buffer, pH 8.0, to $\mathrm{OD}_{600} 250$. DBTO $(200 \mu \mathrm{M})$ was added and the suspension was incubated overnight under ${ }^{18} \mathrm{O}_{2}$ as described in Methods. GC-MS analysis of BPSi recovered by ethyl acetate extraction revealed singly and doubly labelled BPSi in 1:1 ratio, with the phenolic oxygen labelled in both cases (see text). Therefore the phenolic oxygen and one of the sulphinate oxygens of the parent HBPSi- ${ }^{-}$were labelled and hence derived from molecular oxygen.

BPSo was not a substrate for DszB or DszC (Table 2). Thus DszA catalysed two reactions, $\mathrm{DBTO}_{2} \rightarrow \mathrm{HBPSi}^{-}$ and BPSo $\rightarrow$ DHBP.

\section{DszA and DszC catalyse NADH-dependent reactions}

Ohshiro et al. (1994) reported that the conversion of DBT to HBP by cell-free extracts of $R$. erythropolis strain D1 was strongly stimulated by NADH and it was concluded that at least one of the enzymes of the pathway must be NADH-dependent. To identify the $\mathrm{NADH}$-dependent step(s), the individual enzymes were assayed in cell-free extracts of strain IGTS8, in the presence and absence of NADH. The results of these experiments are given in Table 3. The DszB-catalysed reaction, $\mathrm{HBPSi}^{-} \rightarrow \mathrm{HBP}$, was $\mathrm{NADH}$-independent and the DszA-catalysed reaction, BPSo $\rightarrow$ DHBP, was $\mathrm{NADH}$-dependent. The conversion of $\mathrm{DBTO}_{2}$ to $\mathrm{HBP}$, which requires both DszA and DszB (Fig. 4), was $\mathrm{NADH}$-dependent and it was concluded that the DszAcatalysed step, $\mathrm{DBTO}_{2} \rightarrow \mathrm{HBPSi}^{-}$, was NADH-dependent since the following step, $\mathrm{HBPSi}^{-} \rightarrow \mathrm{HBP}$, catalysed by DszB, was NADH-independent. Conversion of DBT and DBTO to HBP was NADH-dependent, but this did not prove that the DszC-catalysed conversion of DBT to DBTO and $\mathrm{DBTO}_{2}$ required $\mathrm{NADH}$, due to the dependence of the following, DszA-catalysed, step $\left(\mathrm{DBTO}_{2} \rightarrow \mathrm{HBPSi}^{-}\right)$. However, the production of $\mathrm{DBTO}_{2}$ from DBT was NADH-dependent in cell-free extracts of Rhodococcus sp. strain CPE362(pENOK3), which produced DszC only (Table 3 ). Based on these results, it was concluded that DszC and DszA, but not DszB catalyse NADH-dependent reactions (Fig. 4).

No significant stimulation of activity in cell-free extracts was observed on addition of NADPH, as found by Ohshiro et al. (1994) (data not shown).

\section{The phenolic oxygen of HBP is derived from molecular oxygen}

Strain IGTS8 was incubated with unlabelled DBT, DBTO or DBTO $_{2}$ in an ${ }^{18} \mathrm{O}_{2}$ atmosphere and the recovered metabolites were analysed by GC-MS to ascertain their oxygen labelling patterns. The HBP recovered from all three incubations was exclusively ${ }^{18} \mathrm{O}$-labelled (molecular ion peak at $m / e=172$ ). No unlabelled HBP (molecular ion peak at $m / e=170$ ) could be detected and it was concluded that the phenolic oxygen was derived exclusively from molecular oxygen. The possibility of rearrangement involving transfer of a sulphone oxygen to carbon during $\mathrm{C}-\mathrm{S}$ bond cleavage was excluded on the basis that no unlabelled HBP was produced in incubations with DBTO or $\mathrm{DBTO}_{2}$.

To determine the ${ }^{18} \mathrm{O}_{2}$ labelling pattern of $\mathrm{HBPSi}^{-}$it was necessary to take into account the fact that this compound was recovered as BPSi, with loss of a sulphinate oxygen (Fig. 1). In a control experiment unlabelled BPSi was hydrolysed in $\mathrm{H}_{2}{ }^{18} \mathrm{O}$, and then recondensed by addition of $\mathrm{HCl}$ to $\mathrm{pH} 1$. The $\mathrm{BPSi}$ recovered by ethyl acetate extraction was unlabelled $\left({ }^{16} \mathrm{O}^{16} \mathrm{O}\right] \mathrm{BPSi}$; molecular ion peak at $\left.m / e=216\right)$ and singly labelled $\left(\left[{ }^{16} \mathrm{O}^{18} \mathrm{O}\right] \mathrm{BPS} ;\right.$; molecular ion peak at $m / e=218$ ) in $1: 1$ ratio. Therefore an ${ }^{18} \mathrm{O}$ atom was incorporated into the sulphinate group on hydrolysis, giving $\left[{ }^{16} \mathrm{O}^{18} \mathrm{O}\right] \mathrm{HBPSi}^{-}$which lost either the labelled or the unlabelled sulphinate oxygen, with equal probability, on recondensation to BPSi.

BPSi recovered from the incubation with unlabelled $\mathrm{DBTO}_{2}$ was exclusively singly labelled $(m / e=218)$ and fragment ions at $m / e=188$ and 189 , corresponding to the loss of the phenolic oxygen as $\mathrm{HC}^{18} \mathrm{O}$ or $\mathrm{C}^{18} \mathrm{O}$, were present (Olson et al., 1993). Therefore the label was 


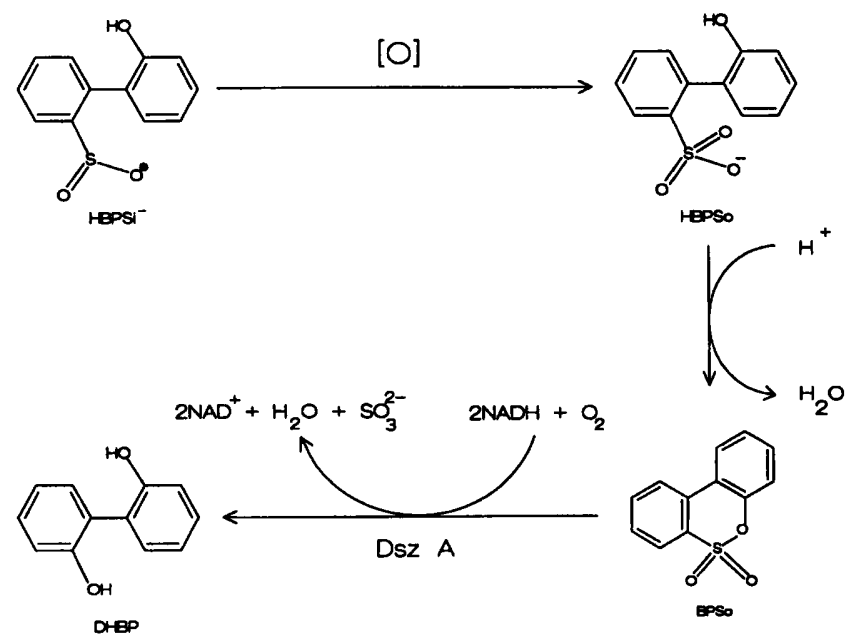

Fig. 6. Suggested pathway for the desulphurization of DBT to DHBP. The committing step would be the oxidation of $\mathrm{HBPSi}^{-}$ to HBPSO$^{-}$. At neutral $\mathrm{pH}$ and physiologically relevant temperatures $\mathrm{HBPSO}^{-}$would spontaneously, and presumably rapidly, condense to give BPSo, a substrate for DszA (Table 1).

present on the phenolic oxygen, as expected given that the phenolic oxygen of the recovered HBP was also labelled.

BPSi recovered from the incubation with unlabelled DBTO was distributed between singly labelled (molecular ion peak at $m / e=218$ ) and doubly labelled (molecular ion peak at $m / e=220$ ) species, in 1:1 ratio (Fig. 5). Fragment ions were present at $m / e=187$ and 188 , again corresponding to the loss of $\mathrm{HC}^{18} \mathrm{O}$ or $\mathrm{C}^{18} \mathrm{O}$ from singly labelled BPSi $(m / e=218)$, and at $m / e=$ 189 and 190 , corresponding to loss of same from the doubly labelled $(m / e=220)$ species. Therefore the phenolic oxygen of $\mathrm{HBPSi}^{-}$was derived from molecular oxygen. This meant that only one of the sulphinate oxygens could be labelled and the presence of singly and doubly labelled BPSi in 1:1 ratio was consistent with the loss with equal probability of either the labelled or the unlabelled sulphinate oxygen from $\mathrm{HBPSi}^{-}$on condensation (Fig. 5). Since the starting material was unlabelled DBTO it was therefore concluded that both the second (sulphone) and third (phenolic) oxygens were derived from ${ }^{18} \mathrm{O}_{2}$.

Finally, DBTO recovered from the incubation of unlabelled DBT with strain IGTS8 under ${ }^{18} \mathrm{O}_{2}$ was exclusively singly labelled (molecular ion peak at $\mathrm{m} / e=$ 202), indicating that the sulphoxide oxygen was derived from molecular oxygen. It was therefore concluded that the oxygen atom incorporated at each step in the sequence DBT $\rightarrow$ DBTO $\rightarrow \mathrm{DBTO}_{2} \rightarrow \mathrm{HBPSi}^{-}$(Fig. 4) was derived from molecular oxygen.

\section{A pathway for the desulphurization of DBT to DHBP}

DHBP was detected as a product of the action of DszA on BPSo (Table 1). A suggested pathway to DHBP is shown in Fig. 6. The committing step would be the
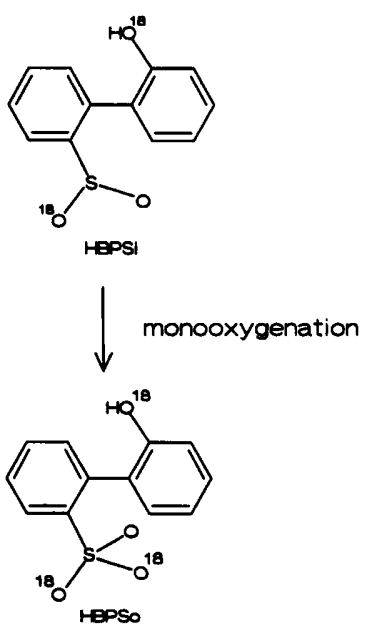

$\downarrow$ condensation

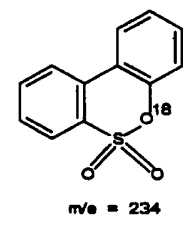

EXPECTED OBTAINED
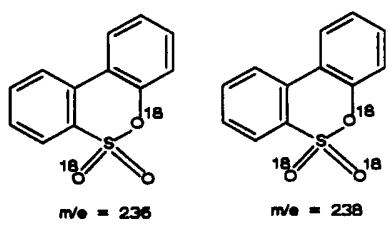

1

14
Fig. 7. ${ }^{18} \mathrm{O}$ labelling profile of BPSo. It was hypothesized that BPSO could be derived from $\mathrm{HBPSi}^{-}$by direct mono-oxygenation of the sulphinate moiety, yielding $\mathrm{HBPSO}^{-}$, which would spontaneously condense, with loss of a water molecule, to give BPSo. If this were the case, BPSo obtained from the incubation of strain IGTS8 with DBTO under ${ }^{18} \mathrm{O}_{2}$ would be triply and doubly labelled in the ratio $1: 2$. In fact the recovered material was singly, doubly and triply labelled in the ratio $8: 86: 14$, and it was concluded that BPSo was not formed as a result of monooxygenase action on $\mathrm{HBPSi}^{-}$.

oxidation of $\mathrm{HBPSi}^{-}$to $\mathrm{HBPSo}^{-}$. At $\mathrm{pH} 8.0$ and $30^{\circ} \mathrm{C}$ the $\mathrm{HBPSo}^{-} \leftrightarrow$ BPSo equilibrium lies very strongly in favour of BPSo (data not shown), and it is expected that $\mathrm{HBPSo}^{-}$would spontaneously, and presumably rapidly, condense to BPSo.

It was further postulated that oxidation of $\mathrm{HBPSi}^{-}$to HBPSo $^{-}$could be due to the action of a cellular monooxygenase. Sufficient BPSo for mass-spectroscopic analysis was recovered from the incubation of strain IGTS8 with unlabelled DBTO under ${ }^{18} \mathrm{O}_{2}$. This is the same incubation which yielded doubly labelled $\mathrm{HBPSi}^{-}$ (Fig. 5) and if $\mathrm{HBPSo}^{-}$originated by mono-oxygenation of $\mathrm{HBPSi}^{-}$the recovered BPSo would be expected to be triply and doubly labelled in 1:2 ratio (Fig. 7). However, the material was singly, doubly and triply labelled (molecular ion peaks at $m / e=234,236$ and 238, respectively) in the ratio $8: 86: 14$, far from the expected value. In fact, ratios consistent with the simple monooxygenation of $\mathrm{HBPSi}^{-}$were never obtained in any incubation which yielded enough BPSo for mass-spec- 
troscopic analysis and it was concluded that $\mathrm{HBPSo}^{-}$is not derived from $\mathrm{HBPSi}^{-}$by this route. However, this result does not necessarily invalidate the pathway given in Fig. 6, since other mechanisms of $\mathrm{HBPSi}^{-}$oxidation cannot be ruled out (see Discussion).

\section{Molecular oxygen is incorporated in the DszA- catalysed conversion of BPSO to DHBP}

When strain IGTS8 was incubated with unlabelled BPSo in an ${ }^{18} \mathrm{O}_{2}$ atmosphere the DHBP produced was exclusively singly labelled (molecular ion peak at $\mathrm{m} / e$ 188). Therefore the original phenolic oxygen was retained and the new one was derived by direct incorporation of molecular oxygen.

\section{DISCUSSION}

The $d s z$ operon encodes three proteins, DszA, B and C, which are necessary and sufficient to confer the DBT desulphurization phenotype on Rhodococcus sp. strain IGTS8. The products of the reaction are HBP and sulphite. The reaction requires molecular oxygen and $\mathrm{NADH}$. Although the functional stoichiometry with respect to these reactants has not yet been measured, the overall reaction is reasonably written (for neutral $\mathrm{pH})$ :

$$
\begin{aligned}
& \mathrm{DBT}+3 \mathrm{O}_{2}+4 \mathrm{NADH}+2 \mathrm{H}^{+} \rightarrow \mathrm{HBP}+\mathrm{SO}_{3}^{2-} \\
& +3 \mathrm{H}_{2} \mathrm{O}+4 \mathrm{NAD}^{+}
\end{aligned}
$$

The four-step pathway is shown in Fig. 4.

The oxygen-labelling studies presented here are entirely consistent with the recent study by Lei \& Tu (1996) on purified DszC. The data show unequivocally that DszC is a mono-oxygenase which is able to catalyse the sequential sulphoxidation reaction, DBT $\rightarrow$ DBTO $\rightarrow$ $\mathrm{DBTO}_{2}$ (Fig. 4). The balanced overall reaction is (for neutral $\mathrm{pH})$ :

$$
\begin{aligned}
& \mathrm{DBT}+2 \mathrm{O}_{2}+2 \mathrm{NADH}+2 \mathrm{H}^{+} \rightarrow \mathrm{DBTO}_{2} \\
& +2 \mathrm{NAD}^{+}+2 \mathrm{H}_{2} \mathrm{O}
\end{aligned}
$$

Recent work by our group (Gray et al., 1996; Xi et al., 1997) and by Lei \& Tu (1996), has shown that purified DszC requires reduced $\mathrm{FMNH}_{2}$ as a cosubstrate (the purified enzyme contains no bound FMN cofactor). An NADH-dependent FMN oxidoreductase has been identified in strain IGTS8. This $25 \mathrm{kD}$ a protein, which is not encoded by the $d s z$ operon, presumably serves as a source of $\mathrm{FMNH}_{2}$ for DszC in vivo (Gray et al., 1996). Since DszC is active in E. coli strain MZ-1(pSAD269$2 \mathrm{~A}$ ), which contains $d s z C$ only (this work; Denome et al., 1994), it seems that a native E. coli FMN oxidoreductase is available to supply $\mathrm{FMNH}_{2}$ to $\mathrm{DszC}$ in the recombinant strain.

The requirement for $\mathrm{FMNH}_{2}$ as co-substrate implies the involvment of flavin 4a-hydroperoxide as the oxygen donor to the substrate and the same general reaction mechanism as for other flavin-dependent mono-oxygenases (Ballou, 1984). However, it is worth noting that
DszC is exceptional in that $\mathrm{FMNH}_{2}$ is required as a cosubstrate, whereas the classical flavin-dependent monooxygenases utilize a bound FAD cofactor. DszC is also exceptional in that it can oxidize DBT to the sulphone; more usually the oxidation of organic sulphides, by both flavin-monoxygenases and haem-dependent enzymes such as horseradish peroxidase or cytochrome P450, proceeds only as far as the sulphoxide, with further oxidation to the sulphone occurring much more slowly, or not at all (Holland, 1988; Dordick et al., 1991). The substrate specificity of DszC has not been fully investigated, but the purified enzyme is also capable of catalysing the oxidation of benzyl sulphide to the sulphone (Lei \& Tu, 1996), thus implying a fairly relaxed substrate specificity.

DszA catalyses two reactions, $\mathrm{DBTO}_{2} \rightarrow \mathrm{HBPSi}^{-}$and BPSo $\rightarrow$ DHBP + sulphite. Both require molecular oxygen and are NADH-dependent. The balanced overall equations at neutral $\mathrm{pH}$ are:

$$
\begin{aligned}
& \mathrm{DBTO}_{2}+2 \mathrm{NADH}+\mathrm{H}^{+}+\mathrm{O}_{2} \rightarrow 2 \mathrm{NAD}^{+} \\
& +\mathrm{H}_{2} \mathrm{O}+\mathrm{HBPSi}^{-}
\end{aligned}
$$

and

$$
\mathrm{BPSo}+2 \mathrm{NADH}+\mathrm{O}_{2} \rightarrow 2 \mathrm{NAD}^{+}+\mathrm{DHBP}+\mathrm{SO}_{3}^{2-}
$$

There is no net oxidation in the conversion of $\mathrm{DBTO}_{2}$ to $\mathrm{HBPSi}^{-}$and a reasonable enzymic mechanism for this reaction would be a base-catalysed hydrolysis (attack of the $\mathrm{C}-\mathrm{S}$ carbon by hydroxide followed by expulsion of sulphinate as the better leaving group). Indeed $\mathrm{HBPSi}^{-}$is one product of the reaction of $\mathrm{DBTO}_{2}$ with $\mathrm{KOH} /$ crown ether (Squires et al., 1981). However, since DszA required NADH for activity in cell-free extracts, and since the phenolic oxygen introduced via the DszAcatalysed reaction was always derived from molecular oxygen, it was concluded that DszA must use a monooxygenation, rather than a hydrolytic, mechanism. Gray et al. (1996) have shown that this enzyme, like DszC, utilizes $\mathrm{FMNH}_{2}$, apparently derived fom the $25 \mathrm{kDa}$ NADH-dependent FMN oxidoreductase, as a cosubstrate. A reasonable mechanism for DszA is shown in Fig. 8. $\mathrm{FMNH}_{2}$ would bind to DszA and then react with molecular oxygen to give the $4 \mathrm{a}$-hydroperoxide. This molecule would attack a $\mathrm{C}-\mathrm{S}$ carbon of the substrate $\left(\mathrm{DBTO}_{2}\right.$, in Fig. 8), leading to its cleavage by expulsion of sulphinate. The resulting peroxide intermediate would be decomposed by attack of hydride, provided by a molecule of NADH, to yield the products $\mathrm{HBPSi}^{-}$and $4 \mathrm{a}$-hydroxy FMNH, which would spontaneously lose a water molecule to regenerate FMN and leave the active site.

The same mechanism applied to BPSo (eqn 4) would yield directly the $O$-sulphite ester of DHBP, which would hydrolyse to DHBP and sulphite with a half-life of seconds (Oae, 1991). The mechanism applied to BPSo is consistent with the formation of sulphite (Table 1) and with ${ }^{18} \mathrm{O}_{2}$-labelling experiments which showed that the phenolic oxygen incorporated at this step was derived from molecular oxygen. 


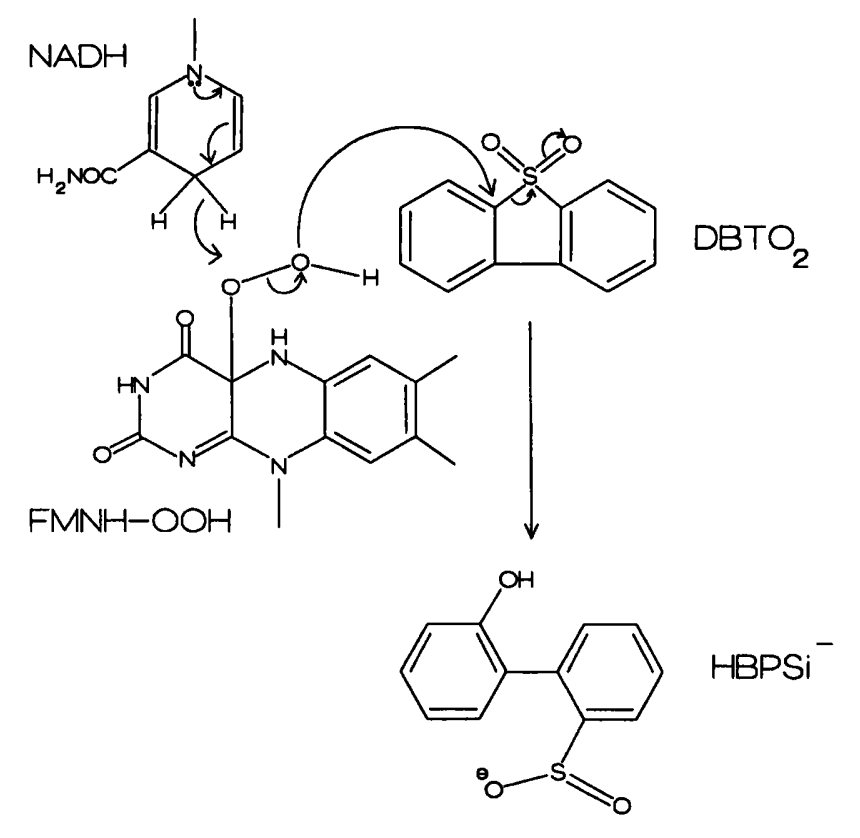

Fig. 8. Proposed mechanism for the DszA-catalysed conversion of $\mathrm{DBTO}_{2}$ to $\mathrm{HBPSi}^{-}$. The active site of DszA is represented as having binding sites for $\mathrm{DBTO}_{2}, \mathrm{FMNH}_{2}$ and NADH. A reasonable mechanism involves binding of $\mathrm{DBTO}_{2}$ and $\mathrm{FMNH}_{2}$ as the first stage. $\mathrm{FMNH}_{2}$ would then react with a molecule of dioxygen, resulting in the formation of FMNH 4ahydroperoxide. This molecule would attack a C-S carbon of the substrate, leading to the cleavage of the C-S bond by expulsion of sulphinate. The resulting peroxide intermediate would be decomposed by hydride attack (provided by NADH) to give the products $\mathrm{HBPSi}^{-}$and 4a-hydroxyFMNH, which would spontaneously lose a water molecule to regenerate FMN. For simplicity, only the reduced nicotinamide moiety of NADH and the core isoalloxazine moiety of FMNHOOH are shown.

The overall reaction stoichiometries given in eqns 3 and 4 are consistent with this mechanism, given that one molecule of NADH would be consumed in the initial reduction of FMN.

DszB catalysed the conversion of $\mathrm{HBPSi}^{-}$to $\mathrm{HBP}+$ sulphite (Table 2). The reaction did not require NADH (Table 3). On this basis DszB is classified as an aromatic sulphinic acid hydrolase catalysing the reaction

$\mathrm{HBPSi}^{-}+\mathrm{H}_{2} \mathrm{O} \rightarrow \mathrm{HBP}+\mathrm{SO}_{3}^{2-}+2 \mathrm{H}^{+}$

A reasonable mechanism invokes the nucleophilic attack of a base-activated water molecule on the sulphinate sulphur (Fig. 9).

It was concluded that BPSo was not an intermediate on the DBT $\rightarrow$ HBP pathway (Fig. 4), since the desulphurized product is DHBP, not HBP, and no other fate for BPSo could be ascertained. Therefore a second pathway was proposed (Fig. 6) to explain the appearance of BPSo and the other desulphurized product, DHBP, in culture media of strain IGTS8 grown on DBT (Gallagher et al., 1993). This pathway was reasonable because the final step, BPSo $\rightarrow$ DHBP + sulphite, has been shown to

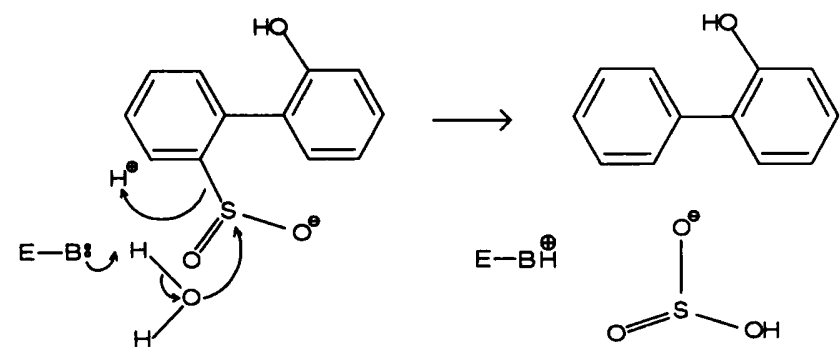

Fig. 9. Proposed mechanism for the DszB-catalysed conversion of $\mathrm{HBPSi}^{-}$to HBP. DszB is represented as E-B:, where $\mathrm{B}$ : is an active-site Lewis base which would activate a water molecule for nucleophilic attack on the sulphinate sulphur with release of sulphite (shown as bisulphite), leaving behind a carbanion intermediate which would accept accept a proton to give final product HBP.

be catalysed by DszA, and $\mathrm{HBPSo}^{-}$, once formed, is expected to spontaneously, and probably very rapidly, condense to BPSo. Although the ${ }^{18} \mathrm{O}$ labelling data do not support conversion of $\mathrm{HBPSi}^{-}$to HBPSo ${ }^{-}$by monooxygenase action, the pathway (Fig. 6) is not invalidated since it is possible that $\mathrm{HBPSi}^{-}$is oxidized by another mechanism. It is known, for example, that aromatic sulphinic acids may undergo a complex disproportionation reaction which leads to a mixture of products, including the corresponding sulphonic acid (Kice \& Bowers, 1962). Further studies are required in order to ascertain the relevance of such reactions and hence clarify this second pathway.

Whatever the nature of the alternative pathway, desulphurization of DBT to DHBP was quantitatively insignificant compared with desulphurization to HBP under standard assay conditions. GC-MS analysis of ethyl acetate extracts of many different samples showed that the HBP:DHBP ratio was variable, but always $>100: 1$. Furthermore, there was no evidence for growth-dependent metabolic switching between HBPand DHBP-yielding pathways, as suggested by Gallagher et al. (1993): DHBP formation from DBT was quantitatively insignificant in both exponentially growing and stationary-phase cultures (data not shown). Since the specific activity of whole-cells and cell-free extracts of strain IGTS8 for BPSo $\rightarrow$ DHBP was similar to that for DBT $\rightarrow$ HBP (Tables 1 and 3), the rate-limiting step in this second pathway must precede BPSo formation.

This work has permitted several ambiguities apparent in earlier studies to be resolved. Firstly, it has been shown that DBTO is an intermediate in the pathway in vivo (a point of minor controversy; Denome et al., 1994). Secondly, $\mathrm{DBTO}_{2}$ is an intermediate on the main pathway to HBP; Gallagher et al. (1993) placed $\mathrm{DBTO}_{2}$ on a pathway to DHBP. Thirdly, again referring to the pathway of Gallagher et al. (1993), BPSo, not $\mathrm{HBPSo}^{-}$, is the immediate precursor of DHBP.

The pathway for DBT desulphurization by strain IGTS8 may be compared with that for Corynebacterium sp. strain SY1 (Omori et al., 1992). The sequence DBT $\rightarrow$ 
DBTO $\rightarrow \mathrm{DBTO}_{2} \rightarrow \mathrm{X} \rightarrow \mathrm{HBP}+$ sulphite was deduced, and it was suggested that $\mathrm{X}$ was biphenyl 2-sulphonate. On the basis of the work presented here, $\mathrm{X}$ is $\mathrm{HBPSi}^{-}$. It is almost certainly the case that the DBT-desulphurization pathways of Rhodococcus sp. strain IGTS8, R. erythropolis strain D-1 and Corynebacterium sp. strain SY1 are identical, and that the $d s z$ operon is common to all three of these isolates.

\section{ACKNOWLEDGEMENTS}

Our thanks to C. Lora (University of Notre Dame) and D. Kaiser (Energy Biosystems Corp.) for technical assistance.

\section{REFERENCES}

Ballou, D. P. (1984). Flavoprotein mono-oxygenases. In Flavins and Flavoproteins, pp. 606-615. Edited by R. C. Bray, P. C. Engel \& S. G. Mayhew. Berlin: Walter de Gruyter.

Beutler, H.-O. (1987). Sulfite determination: sulfite oxidase. Methods Enzymol 147, 11-14.

CONCAWE (1994). Motor vehicle emission regulations and fuel specifications, 1994 update. Report no. 4/94, CONCAWE (Brussels).

Denome, S. A., Olson, E. S. \& Young, K. D. (1993). Identification and cloning of genes involved in specific desulphurisation of dibenzothiophene by Rhodococcus sp. strain IGTS8. Appl Environ Microbiol 59, 2837-2843.

Denome, S. A., Oldfield, C., Nash, L. J. \& Young, K. (1994). Characterisation of the desulfurization genes from $R$ bodococcus sp. strain IGTS8. J Bacteriol 176, 6707-6716.

Dordick, J. S., Keungarp, R. \& McEldoon, J. P. (1991). Enzymatic catalysis on coal-related compounds in organic media: kinetics and potential commercial applications. Resour Conserv Recycl 5, 195-209.

Gallagher, J. R., Olson, E. S. \& Stanley, D. C. (1993). Microbial desulfurization of dibenzothiophene: a sulfur-specific pathway. FEMS Microbiol Lett 107, 31-36.

Gray, K. A., Pogrebinsky, O. S., Mrachko, G. T., Xi, L., Monticello, D. J. \& Squires, C. H. (1996). Molecular mechanisms of biocatalytic desulfurization of fossil fuels. Nat Biotechnol 14, 1705-1709.

Hanson, G. \& Kemp, D. S. (1981). Convenient routes to $4,4^{\prime \prime}$ functionalised o-terphenyls and $2,2^{\prime}$ functionalised biphenyls. $J$ Org Chem 46, 5441-5443.

Holland, H. B. (1988). Chiral sulfoxidation by biotransformation of organic sulphides. Chem Rev 88, 473-485.
Izumi, Y., Ohshiro, T., Ogino, H., Hine, Y. \& Shimao, M. (1994). Selective desulfurization of dibenzothiophene by Rhodococcus erythropolis strain D-1. Appl Environ Microbiol 60, 223-226.

Kayser, K. J., Bielaga-Jones, B. A., Jackowski, K., Odusan, O. \& Kilbane, J. J. (1993). Utilization of organosulphur compounds by axenic and mixed cultures of Rbodococcus rhodochrous strain IGTS8. J Gen Microbiol 139, 3123-3129.

Kice, J. L \& Bowers, K.W. (1962). The mechanism of the disproportionation of sulfinic acids. J Am Chem Soc 84, 605-610.

Lei, B. \& Tu, S.-C. (1996). Gene overexpression, purification and identification of a desulfurization enzyme from $R$ hodococcus $\mathrm{sp}$. strain IGTS8 as a sulfide/sulfoxide monooxygenase. J Bacteriol 178, 5699-5705.

Li, M. Z., Squires, C. H. \& Childs, J. D. (1996). Genetic analysis of the $d s z$ promoter and associated regulatory regions of Rhodococcus erythropolis IGTS8. J Bacteriol 178, 6409-6418.

Oae, S. (1991). Organic Sulphur Chemistry: Structure and Mechanism, p. 155. Boca Raton, FL: CRC Press.

Ohshiro, T., Hine, Y. \& Izumi, Y. (1994). Enzymatic desulphurization of dibenzothiophene by a cell-free system of Rhodococcus erythropolis D-1. FEMS Microbiol Lett 118, 341-344.

Ohshiro, T., Hine, Y. \& Izumi, Y. (1996a). Desulfurization of dibenzothiophene derivatives by whole cells of Rhodococcus erythropolis strain H-2. FEMS Microbiol Lett 142, 65-70.

Ohshiro, T., Suzuki, K. \& Izumi, Y. (1996b). Regulation of dibenzothiophene-degrading activity of Rhodococcus erythropolis strain D-1. J Ferment Bioeng 81, 121-124.

Olson, E. S., Stanley, D. C. \& Gallagher, J. R. (1993). Characterisation of intermediates in the microbial desulfurization of dibenzothiophene. Energy Fuels 7, 159-164.

Omori, T., Monna, L., Saiki, Y. \& Kodama, T. (1992). Desulfurization of dibenzothiophene by Corynebacterium sp. strain SY1. Appl Environ Microbiol 58, 911-915.

Piddington, C. S., Kovacevich, B. R. \& Rambosek, J. (1995). Sequence and molecular characterisation of a DNA region encoding the dibenzothiophene desulfurization operon of Rhodococcus sp. strain IGTS8. Appl Environ Microbiol 61, 468-475.

Squires, T. G., Venier, C. G., Hodgson, B. A. \& Chang, L. W. (1981). Preparation, characterisation and flash vacuum pyrolysis of dibenz[c,e][1,2]oxathiin 6-oxide (biphenylene sultine). J Org Chem 46, 2373-2376.

Xi, L., Squires, C. H., Monticello, D. J \& Childs, J. D (1997). A flavin reductase stimulates DszA and DszC proteins of Rhodococcus erythropolis IGTS8 in vitro. Biochem Biophys Res Commun 230, 73-75.

Received 20 December 1996; revised 18 April 1997; accepted 17 June 1997. 